\title{
Isoprene emissions in Africa inferred from OMI observations of formaldehyde columns
}

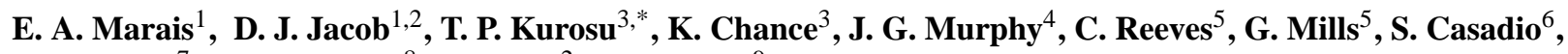 \\ D. B. Millet ${ }^{7}$, M. P. Barkley ${ }^{8}$, F. Paulot ${ }^{2}$, and J. Mao $^{9}$ \\ ${ }^{1}$ Earth and Planetary Sciences, Harvard University, Cambridge, MA, USA \\ ${ }^{2}$ School of Engineering and Applied Sciences, Harvard University, Cambridge, MA, USA \\ ${ }^{3}$ Harvard-Smithsonian Center for Astrophysics, Cambridge, MA, USA \\ ${ }^{4}$ Department of Chemistry, University of Toronto, Toronto, Canada \\ ${ }^{5}$ School of Environmental Sciences, University of East Anglia, Norwich, UK \\ ${ }^{6}$ Instrument Data quality Evaluation and Analysis (IDEAS), Serco Spa Via Sciadonna 24, 00044 Frascati (Roma), Italy \\ ${ }^{7}$ Department of Soil, Water and Climate, University of Minnesota, St. Paul, MN, USA \\ ${ }^{8}$ Space Research Centre, University of Leicester, Leicester, UK \\ ${ }^{9}$ Atmospheric and Oceanic Sciences, Princeton University, Princeton, NJ, USA \\ * now at: Earth Atmosphere Science, Jet Propulsion Laboratory, Pasadena, CA, USA
}

Correspondence to: E. A. Marais (emarais@fas.harvard.edu)

Received: 21 February 2012 - Published in Atmos. Chem. Phys. Discuss.: 15 March 2012

Revised: 12 June 2012 - Accepted: 20 June 2012 - Published: 18 July 2012

\begin{abstract}
We use 2005-2009 satellite observations of formaldehyde (HCHO) columns from the OMI instrument to infer biogenic isoprene emissions at monthly $1 \times 1^{\circ}$ resolution over the African continent. Our work includes new approaches to remove biomass burning influences using OMI absorbing aerosol optical depth data (to account for transport of fire plumes) and anthropogenic influences using AATSR satellite data for persistent small-flame fires (gas flaring). The resulting biogenic $\mathrm{HCHO}$ columns $\left(\Omega_{\mathrm{HCHO}}\right)$ from OMI follow closely the distribution of vegetation patterns in Africa. We infer isoprene emission ( $\left.E_{\mathrm{ISOP}}\right)$ from the local sensitivity $S=\Delta \Omega_{\mathrm{HCHO}} / \Delta E_{\mathrm{ISOP}}$ derived with the GEOS-Chem chemical transport model using two alternate isoprene oxidation mechanisms, and verify the validity of this approach using AMMA aircraft observations over West Africa and a longitudinal transect across central Africa. Displacement error (smearing) is diagnosed by anomalously high values of $S$ and the corresponding data are removed. We find significant sensitivity of $S$ to $\mathrm{NO}_{\mathrm{x}}$ under low- $\mathrm{NO}_{\mathrm{x}}$ conditions that we fit to a linear function of tropospheric column $\mathrm{NO}_{2}$. We estimate a $40 \%$ error in our inferred isoprene emissions under high- $\mathrm{NO}_{\mathrm{x}}$ conditions and 40-90\% under low- $\mathrm{NO}_{\mathrm{x}}$ conditions. Our results suggest that isoprene emission from the central African rainforest is much lower than estimated by the state-of-the-science MEGAN inventory.
\end{abstract}

\section{Introduction}

Isoprene $\left(\mathrm{CH}_{2}=\mathrm{C}\left(\mathrm{CH}_{3}\right) \mathrm{CH}=\mathrm{CH}_{2}\right)$ is the dominant nonmethane volatile organic compound (NMVOC) emitted by vegetation, accounting for about $50 \%$ of global NMVOC emissions according to current inventories (Guenther et al., 1995; Olivier et al., 1996; Arneth et al., 2008). It is a major precursor of organic aerosol (Claeys et al., 2004; Henze and Seinfeld, 2006; Kroll et al., 2006) and of tropospheric ozone (Trainer et al., 1987; Tao et al., 2003; Fiore et al., 2011), thus impacting air quality, climate, and human health. Isoprene also affects the abundance of $\mathrm{OH}$, the main atmospheric oxidant (Lelieveld et al., 2008; Ren et al., 2008). Satellite observations of formaldehyde (HCHO), a high-yield product of isoprene oxidation, can provide useful constraints on isoprene emissions (Palmer et al., 2003). Here we use HCHO satellite observations from the Ozone Monitoring Instrument (OMI) to better quantify isoprene emissions from the African continent. Africa appears as a major isoprene source region in global HCHO satellite data (Meyer-Arnek et al., 2005; De Smedt et al., 2008), yet it has thus far received little attention.

Isoprene emission inventories in atmospheric chemistry models generally follow the Guenther et al. (1995) framework, which uses base emissions for different ecosystem types modulated by local environmental factors. These inventories are constructed by extrapolation of limited 
ecosystem data and best understanding of processes, and are commonly called "bottom-up". Arneth et al. (2008) point out that there is considerable uncertainty in bottom-up isoprene emission inventories, more than is apparent from the spread of values in the literature, as all tend to rely on the same limited data and algorithm framework. Direct isoprene emission measurements in Africa are particularly limited, consisting of a few data for tropical rainforests (Klinger et al., 1998; Greenberg et al., 1999; Serça et al., 2001), woodlands (Greenberg et al., 1999, 2003; Otter et al., 2002), savannas (Guenther et al., 1996; Klinger et al., 1998; Otter et al., 2002; Harley et al., 2003; Saxton et al., 2007), and shrublands (Otter et al., 2002).

An alternate "top-down" approach for estimating abovecanopy isoprene emissions is to use HCHO column measurements made by satellites from solar backscatter in the 330$360 \mathrm{~nm}$ absorption bands (Chance et al., 2000). Isoprene has an atmospheric lifetime of typically less than $1 \mathrm{~h}$ against oxidation by $\mathrm{OH}$, producing $\mathrm{HCHO}$ which has a midday lifetime of $1-2 \mathrm{~h}$ against photolysis and oxidation by $\mathrm{OH}$. This adds to the $\mathrm{HCHO}$ background originating from the oxidation of methane. Thus the HCHO columns measured from space can be related to the underlying isoprene emission (Palmer et al., 2003). Contributions from other biogenic or anthropogenic NMVOCs are generally much weaker because emissions are lower and/or HCHO production is slower (Palmer et al., 2003), although care is needed to screen biomass burning and large anthropogenic influences (Fu et al., 2007; Barkley et al., 2008). Inference of isoprene emissions from HCHO column measurements by the GOME (1995 launch), SCIAMACHY (2002), and OMI (2004) satellite instruments has been reported in a number of studies for North America (Abbot et al., 2003; Palmer et al., 2003, 2006; Millet et al., 2008), Asia (Fu et al., 2007), Europe (Dufour et al., 2009; Curci et al., 2010), South America (Barkley et al., 2008), and globally (Shim et al., 2005; Stavrakou et al., 2009a).

Relating $\mathrm{HCHO}$ columns to isoprene emission requires a quantitative relationship between the two obtained with a chemical transport model (CTM). Most of our current understanding of isoprene chemistry has been developed for high concentrations of nitrogen oxide radicals $\left(\mathrm{NO}_{\mathrm{x}} \equiv \mathrm{NO}+\mathrm{NO}_{2}\right)$ that originate in the atmosphere from combustion sources and soil emissions. Under these high$\mathrm{NO}_{\mathrm{x}}$ conditions $\left(>1 \mathrm{ppb} \mathrm{NO}_{\mathrm{x}}\right)$ the organic peroxy radicals $\left(\mathrm{RO}_{2}\right)$ produced from isoprene oxidation react preferentially with NO. The resulting HCHO yield is relatively well quantified and is mostly realized in the first stage of isoprene oxidation (Palmer et al., 2003; Millet et al., 2006). Under low$\mathrm{NO}_{\mathrm{x}}$ conditions more typical of Africa, the $\mathrm{RO}_{2}$ radicals may instead react with $\mathrm{HO}_{2}$ or isomerize (Peeters et al., 2009), modifying and delaying HCHO yields (Palmer et al., 2003, 2006; Mao et al., 2010). Delay in HCHO production causes smearing in the local relationship between isoprene emission and the HCHO column (Palmer et al., 2003). This smearing can in principle be resolved in a formal inversion account- ing for CTM transport (Shim et al., 2005; Stavrakou et al., 2009a) but there is large uncertainty in the coupling between chemical and transport timescales.

Here we use a 5-yr record of OMI HCHO data (20052009) to constrain isoprene emissions from the African continent. We convert HCHO columns to isoprene emissions by using the GEOS-Chem CTM with updated isoprene chemistry (Paulot et al., 2009a, b). We introduce a new method to screen biomass burning influence based on OMI observations of aerosol absorption optical depth (AAOD) (Torres et al., 2007) and also screen urban and gas flaring influences. We use aircraft observations from the African Monsoon Multidisciplinary Analysis (AMMA) campaign in West Africa during July-August 2006 (Murphy et al., 2010; Reeves et al., 2010; Stone et al., 2010) to test the GEOS-Chem simulation of isoprene chemistry and estimate the smearing in the isoprene-HCHO relationship. We also derive a new approach to account for the $\mathrm{NO}_{\mathrm{x}}$ dependence of the isoprene-HCHO relationship using $\mathrm{OMI} \mathrm{NO}_{2}$ data.

\section{Constructing a data set of OMI biogenic $\mathrm{HCHO}$ columns}

\subsection{Slant columns}

The Ozone Monitoring Instrument (OMI) (Levelt et al., 2006) was launched onboard the Aura satellite in 2004. It has spatial resolution of $13 \times 24 \mathrm{~km}^{2}$ at nadir, an equator crossing time of 13:38 local time (LT), and achieves daily global coverage with a cross-track swath width of $2600 \mathrm{~km}$. HCHO slant columns $\left(\Omega_{\mathrm{s}}\right)$ are a standard product from the OMI instrument, obtained by spectral fitting of backscattered solar radiation in the $327.5-356.5 \mathrm{~nm}$ window (http://www.cfa.harvard.edu/atmosphere/Instruments/OMI/ PGEReleases/READMEs/OMHCHO_README.pdf). We use OMHCHO Version 2.0 (Collection 3) retrievals for 2005-2009 from the NASA Data and Information Services Center (http://disc.sci.gsfc.nasa.gov/Aura/data-holdings/ OMI/omhcho_v003.shtml). We exclude observations that (1) do not pass all fitting and statistical quality checks specified in the standard product (MainDataQualityFlag $=0$ ), (2) have a cloud fraction $>0.4$ determined from the OMI $\mathrm{O}_{2}-\mathrm{O}_{2}$ cloud product (Stammes et al., 2008), or (3) are affected by the OMI row anomaly (http://www.knmi.nl/omi/ research/product/rowanomaly-background.php).

The OMI data feature a slow increase in the baseline $\Omega_{\mathrm{s}}$ with time over 2005-2009 that likely reflects degradation of the instrument. We correct for this using observations over the remote Pacific $\left(40-50^{\circ} \mathrm{S}, 150-160^{\circ} \mathrm{W}\right)$ where the OMI data are essentially noise. Following the methodology of Kim et al. (2011) we fit a 4th order polynomial function to the baseline slant column $\Omega_{\mathrm{s}, \mathrm{b}}$ over that region as a function of time $t$ : 
a. $\mathrm{OMI} \mathrm{HCHO}$ slant columns original data

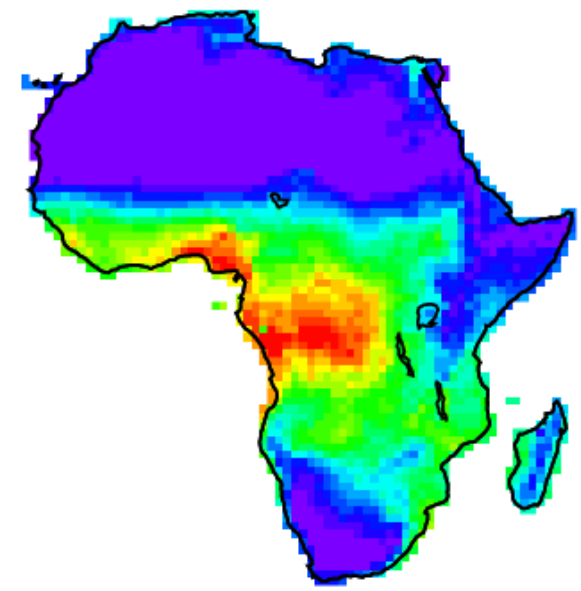

c. OMI HCHO vertical columns biogenic component only

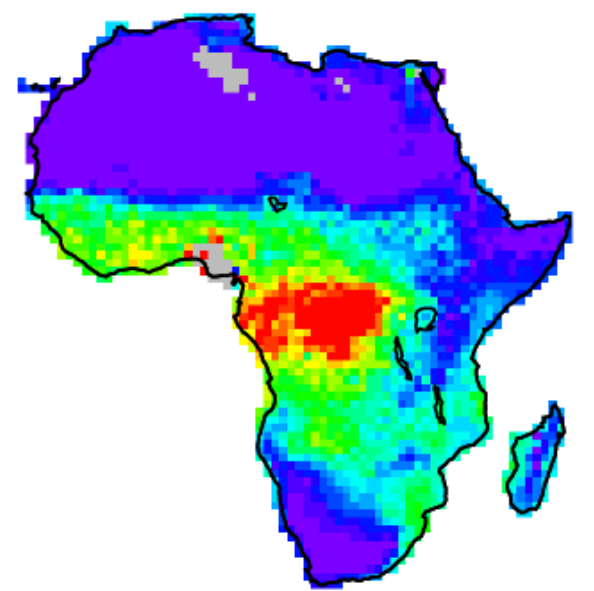

\section{b. $\mathrm{OMI} \mathrm{HCHO}$ slant columns biogenic component only}

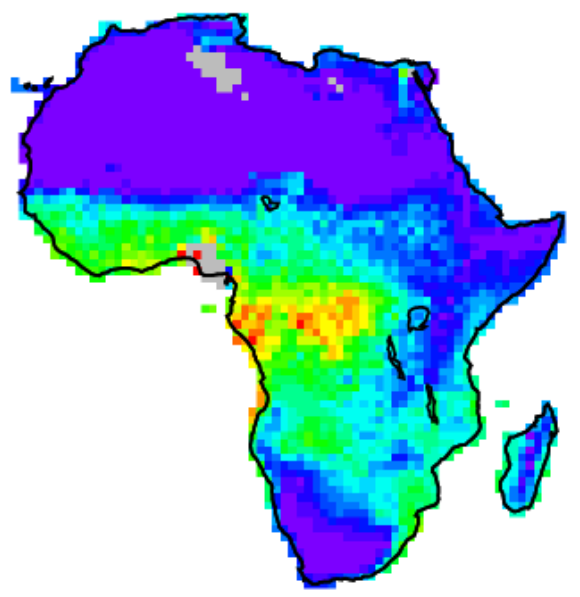

\section{d. GLC 2000 land cover}

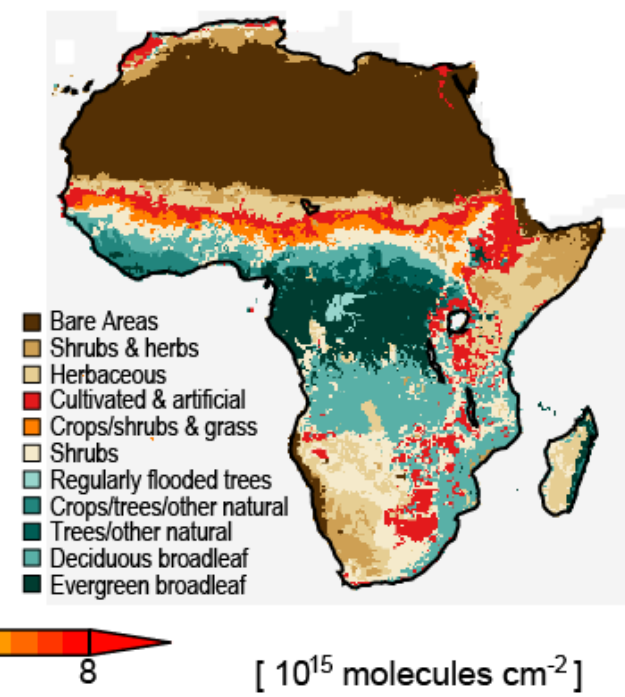

Fig. 1. HCHO columns and land cover types over Africa. The first three panels are annual mean HCHO columns for $2005-2009$ at $1 \times 1^{\circ}$ resolution: (a) original slant columns, (b) biogenic slant columns after removing biomass burning, dust, and anthropogenic influences, (c) vertical columns obtained by applying air mass factors (AMFs) to the slant columns. The bottom right panel (d) shows the Global Land Cover (GLC) map for 2000 (Bartholomé and Belward, 2005).

$$
\begin{aligned}
\Omega_{\mathrm{s}, \mathrm{b}}= & -2.0 \times 10^{3} t^{4}+9.6 \times 10^{6} t^{3}-1.3 \times 10^{10} t^{2} \\
& +7.5 \times 10^{12} t+2.5 \times 10^{15}
\end{aligned}
$$

where $\Omega_{\mathrm{s}, \mathrm{b}}$ is in molecules $\mathrm{cm}^{-2}$ and $t$ is in days ( $t=1$ on 1 January 2005). We remove $\Omega_{\mathrm{s}, \mathrm{b}}$ calculated with Eq. (1) from the OMI measurement of $\Omega_{\mathrm{s}}$ and refer to the residual as $\Omega_{\mathrm{s}}$ in what follows.

We thus compile 8-day average values for $\Omega_{\mathrm{s}}$ on a $1 \times 1^{\circ}$ (lat $\times$ lon) grid for 2005-2009 (Fig. 1a). The slant column fitting uncertainty for a single observation is
$8 \times 10^{15}$ molecules $\mathrm{cm}^{-2}$ on average. 8 -day and $1 \times 1^{\circ}$ averaging reduces the uncertainty to $1-2 \times 10^{15}$ molecules $\mathrm{cm}^{-2}$.

\subsection{Removing biomass burning and anthropogenic influences}

We remove biomass burning and anthropogenic influences from the $\Omega_{\mathrm{s}}$ data in order to isolate the biogenic component. The standard procedure for removing biomass burning is to use space-based observations of fire counts (Jaeglé et al., 2005; Barkley et al., 2008). We begin with this approach by using MODIS day and night fire counts from the 
Terra satellite. The data are provided daily at a resolution of $1 \times 1 \mathrm{~km}^{2}$ (Giglio et al., 2003) and we average them for 8 days on the same $1 \times 1^{\circ}$ grid as $\Omega_{\mathrm{s}}$. We exclude persistent fires associated with large industrial and urban areas of Cairo (Egypt), the Mpumalanga Highveld region (South Africa), and the Niger Delta (Nigeria). We then remove as contaminated by biomass burning all gridsquares with non-zero fire counts for the concurrent and preceding 8-day periods.

Screening only on the basis of fire counts is insufficient as it does not account for the long-range transport of $\mathrm{HCHO}$ in biomass burning plumes. Plume influences on HCHO far downwind of fires in Africa are evident from Lagrangian analyses of satellite data (Meyer-Arnek et al., 2005) and AMMA aircraft data (Janicot et al., 2008; Mari et al., 2008; Murphy et al., 2010; Reeves et al., 2010). Solar backscatter satellite instruments retrieve both $\mathrm{HCHO}$ and $\mathrm{NO}_{2}$, and Barkley et al. (2008) previously used $\mathrm{NO}_{2}$ as an additional filter to screen against biomass burning in tropical South America. However, we find that this filter is insufficient because the atmospheric lifetime of $\mathrm{NO}_{\mathrm{x}}$ emitted from biomass burning is only a few hours, whereas the influence of fires on HCHO is sustained downwind by oxidation of emitted NMVOCs (Hobbs et al., 1996; Trentmann et al., 2003; Alvarado et al., 2010).

Our method to diagnose biomass burning plumes is to use the AAOD product from OMI for the same scenes as HCHO (Torres et al., 2007). Absorbing aerosol is conserved in the plume in the absence of precipitation. We use the level 2 version 3 gridded OMI AAOD product (http://disc.sci.gsfc. nasa.gov/Aura/data-holdings/OMI/omaeruvg_v003.shtml), provided at $0.25 \times 0.25^{\circ}$ horizontal resolution, and average it over 8 -day periods on the same $1 \times 1^{\circ}$ grid as $\Omega_{\mathrm{s}}$. The product includes separate contributions from dust and smoke aerosol but separation between the two can be difficult (Ahn et al., 2008) and we find that smoke AAOD is elevated in dusty regions. To address this problem, we subdivide the continent latitudinally into the Mediterranean strip (north of $\left.20^{\circ} \mathrm{N}\right)$, northern Africa $\left(4-19^{\circ} \mathrm{N}\right)$, equatorial Africa $\left(5^{\circ} \mathrm{S}-4^{\circ} \mathrm{N}\right)$, and southern Africa (south of $\left.5^{\circ} \mathrm{S}\right)$. For each region we plot the 5-yr frequency distribution of OMI smoke AAOD, as shown in Fig. 2 for southern Africa. This separates biomass burning and non-biomass burning scenes into two populations, and we remove the biomass burning scenes. The smoke AAOD thresholds are 0.02, 0.07, 0.05, and 0.04 for the Mediterranean strip, northern Africa, equatorial Africa, and southern Africa, respectively.

Large dust influence is also problematic in the interpretation of HCHO slant columns because of scattering and absorption by the dust. Northern and equatorial Africa can be very dusty. We filter out high dust scenes with the OMI dust AAOD product previously described using a threshold value of 0.1 , above which the radiative interference would be of concern.

The OMI HCHO data show high values over Nigeria (Fig. 1a) that may reflect urban NMVOC emissions in Lagos

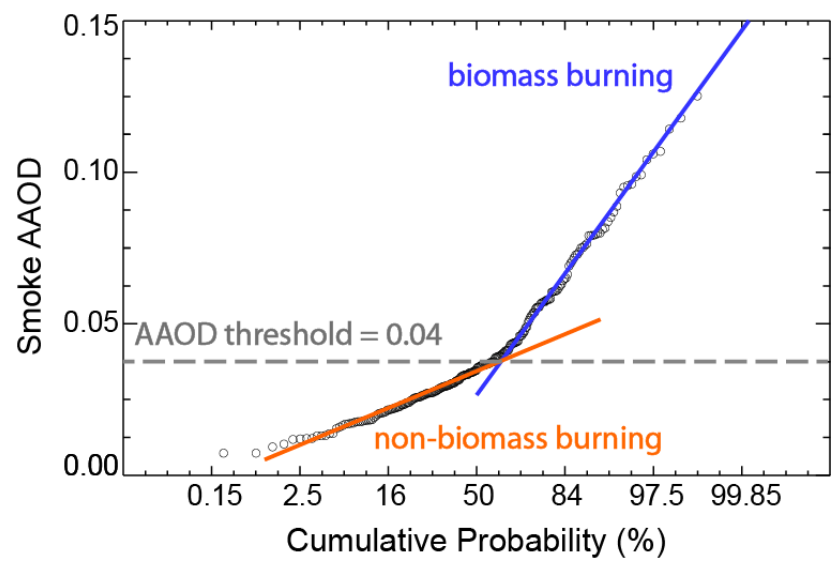

Fig. 2. Cumulative probability distribution of OMI smoke AAOD 8day average values at $1 \times 1^{\circ}$ resolution over southern Africa (south of $5^{\circ} \mathrm{S}$ ) for 2005-2009. The $\mathrm{x}$-axis is a probability scale such that a normal distribution would plot as a straight line. This allows us to separate biomass burning from non-biomass burning conditions by plotting separate regression lines fitted to the bottom and top quantiles of the data. Intersection of these regression lines defines a smoke AAOD threshold for diagnosing biomass burning conditions and we remove the corresponding scenes from the OMI data set. Different AAOD thresholds are used for different regions of Africa as discussed in the text.

(Oketola and Osibanjo, 2007; Hopkins et al., 2009; Reeves et al., 2010), biofuel use that is particularly intense in rural Nigeria (Yevich and Logan, 2003), and gas flaring in the Niger Delta (Casadio et al., 2012). Other African countries that practice gas flaring related to the oil and gas industry include Libya, Algeria, Angola, Egypt, Gabon, Sudan, Congo and Tunisia (Casadio et al., 2012). We remove HCHO associated with gas flaring by using gas flare hotspots retrieved in the $1.6 \mu \mathrm{m}$ band (Algorithm3 or ALGO3) from the Advanced Along Track Scanning Radiometer (AATSR) satellite instrument (Casadio et al., 2012). We average the AATSR fire counts over the same $1 \times 1^{\circ}$ grid and 8-day averaging period as OMI and remove gridsquares with non-zero gas flares. Over Nigeria the enhancements in $\mathrm{HCHO}$ occur beyond the region of flaring, which may reflect pollution transport as well as Lagos emissions and biofuel use. We therefore remove a more extensive $3 \times 3^{\circ}$ area around the gridsquares affected by flaring in Nigeria. The AATSR data do not extend over South Africa due to noise from the South Atlantic Anomaly (Casadio et al., 2012), but we find that the six oil refineries in South Africa (SAPIA, 2008) are not associated with elevated $\mathrm{HCHO}$ in the OMI data of Fig. 1a. We therefore see no need for additional screening.

Our filtering scheme to remove biomass burning, dust, and anthropogenic contributions from the OMI $\Omega_{\mathrm{s}}$ observations is summarized in Fig. 3. It removes $40 \%$ of observations over Africa on average and $70-80 \%$ in the southern hemisphere during the dry season. These excluded areas account 


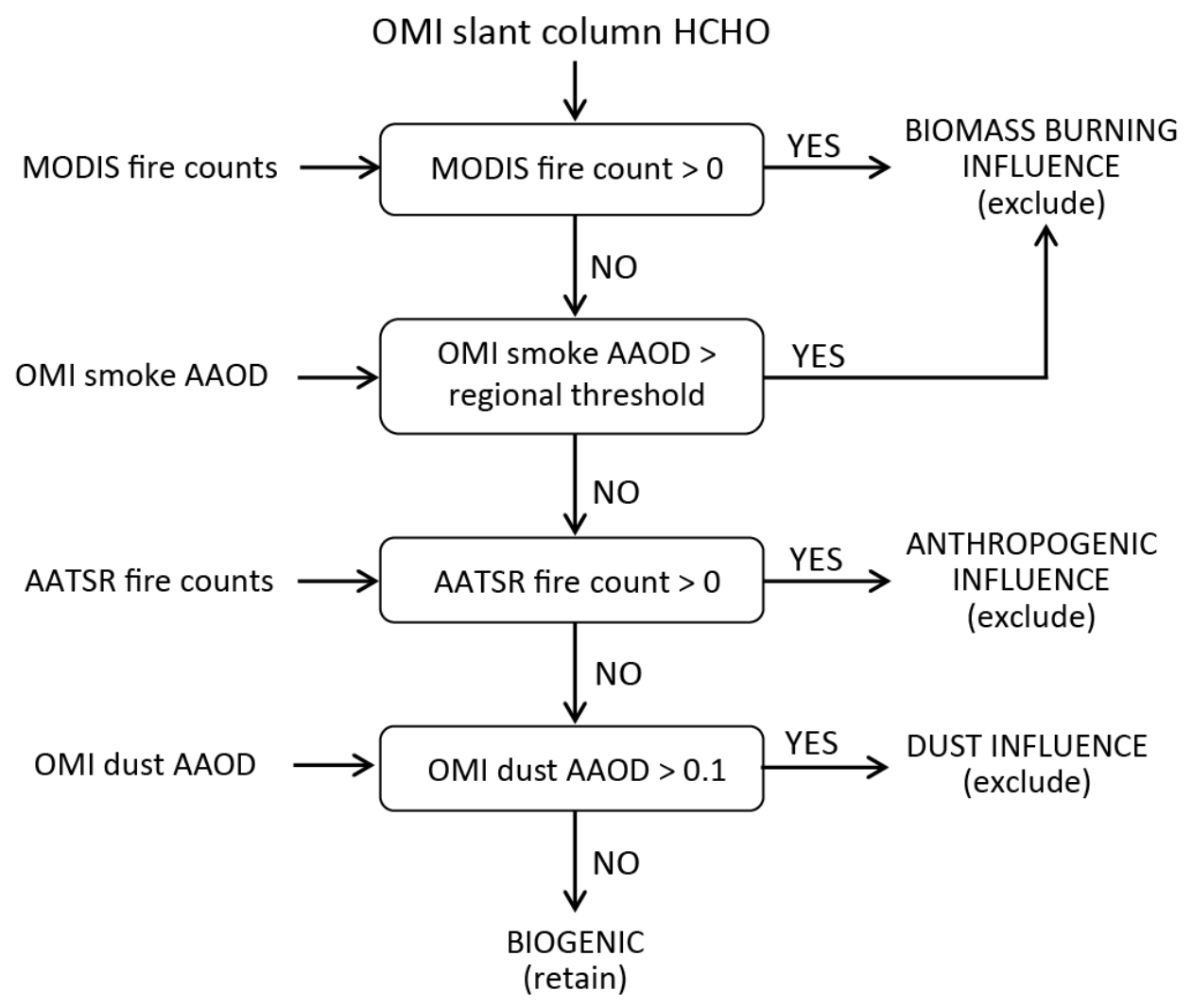

Fig. 3. Flow chart of the filtering algorithm used to remove biomass burning, dust, and anthropogenic influences in OMI slant HCHO columns $\left(\Omega_{\mathrm{S}}\right)$. All data are 8 -day averages on the same $1 \times 1^{\circ}$ grid. The MODIS fire counts filter uses MODIS data for the 8 -day periods preceding and concurrent with the OMI HCHO observation.

for $27 \%$ of African isoprene emissions in the MEGAN inventory (Sect. 3.3). Figure 1 shows the mean OMI $\Omega_{\mathrm{s}}$ observations for 2005-2009 before (a) and after (b) application of the filtering scheme. The filtered observations are taken to represent biogenic $\mathrm{HCHO}$ in what follows.

\subsection{Conversion to vertical columns}

The slant column $\Omega_{\mathrm{s}}$ obtained by spectral fitting is related to the true vertical column $\Omega_{\mathrm{HCHO}}$ by an air mass factor $\left(\mathrm{AMF}=\Omega_{\mathrm{s}} / \Omega_{\mathrm{HCHO}}\right)$ obtained with a radiative transfer model. We use the formulation of Palmer et al. (2001), which calculates the AMF as the vertical integral of the relative vertical distribution of $\mathrm{HCHO}$ (shape factor) weighted by altitude-dependent coefficients (scattering weights). The scattering weights are functions of viewing geometry, surface albedo, and atmospheric scattering by air molecules, aerosols, and clouds. Cloud fraction and cloud top pressure are from the $\mathrm{OMI} \mathrm{O}{ }_{2}-\mathrm{O}_{2}$ cloud product (Stammes et al., 2008). The LIDORT radiative transfer model (Spurr et al., 2001) is used to calculate scattering weights for individual scenes. Clouds are represented by Lambertian surfaces with an albedo of 0.8 , as recommended by Koelemeijer and Stammes (1999), and consistent with the $\mathrm{O}_{2}-\mathrm{O}_{2}$ cloud algorithm. Surface albedo for the African continent is from the OMI reflectance climatology at $345 \mathrm{~nm}$ (Kleipool et al., 2008). HCHO and aerosol vertical distributions are monthly mean values from the GEOS-Chem CTM, described in Sect. 3.

We find that $62 \%$ of the spatial variability in the annual average AMFs over Africa is driven by OMI surface albedo. The AMF is close to unity for much of the continent (average 1.2), with larger values over the Sahara and Namib Deserts (high albedo) and lower values over central Africa (low albedo). Figure 1c shows the resulting annual mean distribution of $\mathrm{HCHO}$ vertical columns $\Omega_{\mathrm{HCHO}}$. We see that most of the variability in $\Omega_{\mathrm{HCHO}}$ is present in the slant column data and thus is not driven by the AMF. The $\Omega_{\mathrm{HCHO}}$ patterns match closely the distribution of major land types in Africa (Fig. 1d), supporting the interpretation of $\mathrm{HCHO}$ as a proxy for isoprene emission. Maximum values are found over evergreen broadleaf forests in the tropics. Low values occur over barren, shrub, herbaceous, and cultivated vegetation. Small-scale biogenic features are apparent such as the forested belt along the east coast of South Africa, crops along the Nile River, and the coastal vegetated Mediterranean strip. 


\section{GEOS-Chem model}

\subsection{General description}

We use the GEOS-Chem global 3-D CTM (version 8-03-01, http://geos-chem.org) to (1) estimate the vertical distribution of $\mathrm{HCHO}$ for use in the AMF calculation and (2) quantify the relationship between isoprene emissions and $\mathrm{HCHO}$ column abundance. GEOS-Chem is driven by Goddard Earth Observing System (GEOS-5) assimilated meteorological data from the NASA Global Modeling and Assimilation Office (GMAO). The GEOS-5 meteorological data have a native horizontal resolution of $0.5 \times 0.67^{\circ}$ with 72 vertical pressure levels and 6-h temporal frequency (3-h for surface variables and mixing depths). We use data for year 2006 and degrade the horizontal resolution to $2 \times 2.5^{\circ}$ for input to GEOS-Chem. The model results presented here are from one year of simulation (2006) following one year of spinup for chemical initialization.

Biogenic emission of isoprene is calculated locally in GEOS-Chem using the MEGAN v2.1 inventory (Guenther et al., 2006), with modifications described below. Anthropogenic emissions of $\mathrm{NO}_{\mathrm{x}}$ in Africa are from the EDGAR v2.0 inventory (Olivier et al., 1996). Biomass burning $\mathrm{NMVOC}$ and $\mathrm{NO}_{\mathrm{x}}$ emissions are from the Global Fire Emissions Database v2 (van der Werf et al., 2006). $\mathrm{NO}_{\mathrm{x}}$ emissions from soils and fertilizer use are from the algorithm of Yienger and Levy (1995) as implemented by Wang et al. (1998).

Dry deposition in GEOS-Chem follows the standard resistance-in-series scheme of Wesely (1989). In that scheme, gases are deposited as determined by their Henry's law solubility and their surface reactivity (referenced to ozone). Here we have updated the dry deposition of $\mathrm{HCHO}$ and other oxygenated products of isoprene oxidation including methyl vinyl ketone (MVK), methacrolein (MACR), glycolaldehyde, and dicarbonyls to have the same surface reactivity as ozone, based on observational evidence of rapid deposition (Sumner et al., 2001; Karl et al., 2004, 2009) and following the recommendation of Karl et al. (2010). We also include in the model wet and dry deposition of isoprene hydroperoxides and epoxydiols using respective Henry's law constants of $1.7 \times 10^{6} \mathrm{M} \mathrm{atm}^{-1}$ (US EPA, 2011) and $1.3 \times 10^{8} \mathrm{M} \mathrm{atm}^{-1}$ (Eddingsaas et al., 2010). We account for the grid-scale transport of isoprene hydroperoxides, which have a sufficiently long lifetime against oxidation by OH (3-5 h; Paulot et al., 2009b) to contribute to spatial displacement (smearing) between isoprene emission and the resulting $\mathrm{HCHO}$ columns. Previous inversions of $\mathrm{HCHO}$ using GEOS-Chem did not include this transport and would therefore underestimate the smearing under low- $\mathrm{NO}_{\mathrm{x}}$ conditions.

\subsection{Improved treatment of isoprene chemistry}

GEOS-Chem includes detailed ozone- $\mathrm{NO}_{\mathrm{x}}$-VOC-aerosol coupled chemistry originally described by Bey et al. (2001) and Park et al. (2004), with recent updates described by Mao et al. (2010). We have updated the rate coefficients for the reactions of $\mathrm{HO}_{2}$ with $>\mathrm{C}_{2}$ peroxy radicals to Eq. (iv) of Saunders et al. (2003). At $298 \mathrm{~K}$ the rate coefficient doubles from 0.8 to $1.6 \times 10^{-11} \mathrm{~cm}^{3}$ molecule ${ }^{-1} \mathrm{~s}^{-1}$ relative to previous versions of GEOS-Chem, increasing the relative importance of the low- $\mathrm{NO}_{\mathrm{x}}$ isoprene oxidation pathway.

The standard isoprene oxidation scheme used in GEOSChem is largely based on Horowitz et al. (1998). As with all conventional schemes, it leads to $\mathrm{OH}$ titration by isoprene under low $-\mathrm{NO}_{\mathrm{x}}$ conditions when the isoprene peroxy radicals (ISOPOO) produced from the isoprene $+\mathrm{OH}$ reaction react with $\mathrm{HO}_{2}$ rather than $\mathrm{NO}$ to form isoprene hydroperoxides (ISOPOOH). This titration is not seen in observations (Lelieveld et al., 2008; Ren et al., 2008). We implement as an alternate isoprene oxidation scheme in GEOSChem the Paulot et al. (2009b) mechanism, where regeneration of $\mathrm{OH}$ under low- $\mathrm{NO}_{\mathrm{x}}$ conditions takes place via oxidation of epoxydiol species produced from oxidation of ISOPOOH. Isomerization of ISOPOO leading to formation of hydroperoxyaldehydes is another pathway for $\mathrm{OH}$ regeneration (Peeters et al., 2009; Peeters and Müller, 2010), but the kinetics are highly uncertain (Crounse et al., 2011; Taraborrelli et al., 2012). We compare below results from the "standard" and "Paulot" schemes to assess the degree of uncertainty in simulating HCHO yields. The "standard" chemistry scheme is that in version 8-03-01 of GEOS-Chem with updated $\mathrm{RO}_{2}+\mathrm{HO}_{2}$ kinetics as described above.

Figure 4 shows the time-dependent yields of $\mathrm{HCHO}$ from isoprene oxidation calculated in the DSMACC box model (Emmerson and Evans, 2009) for the standard and Paulot schemes, as implemented in GEOS-Chem with different $\mathrm{NO}_{\mathrm{x}}$ levels. Each simulation uses fixed concentrations of $\mathrm{O}_{3}$ (28 ppbv), $\mathrm{CO}(150 \mathrm{ppbv})$, and $\mathrm{NO}_{\mathrm{x}}(0.01,0.1$, and $1 \mathrm{ppbv})$. Isoprene is initially $1 \mathrm{ppbv}$ and allowed to decay. The temperature is $298 \mathrm{~K}$. Diurnally varying photolysis frequencies are calculated for clear sky conditions at the Equator with surface albedo of 0.1 and an ozone column of 260 Dobson units. Under high- $\mathrm{NO}_{\mathrm{x}}$ conditions (1 ppbv), we find that the ultimate $\mathrm{HCHO}$ yield is approached within a few hours and is similar for both schemes. Under low- $\mathrm{NO}_{\mathrm{x}}$ conditions $(0.1 \mathrm{ppbv})$, the ultimate yield is $10-20 \%$ lower and takes 1-2 days to achieve, again with similar values for both schemes. The largest difference is under very low $\mathrm{NO}_{\mathrm{x}}$ conditions $(0.01 \mathrm{ppbv})$ where the ultimate yield is $30-40 \%$ lower than under high- $\mathrm{NO}_{\mathrm{x}}$ conditions and the timescale for reaching that yield is 5-6 days. The Paulot scheme does not show a shorter timescale for reaching the ultimate yield than the standard scheme, despite higher $\mathrm{OH}$, because it generates more $\mathrm{HCHO}$ from later-generation isoprene oxidation products. The implications of these results for the 


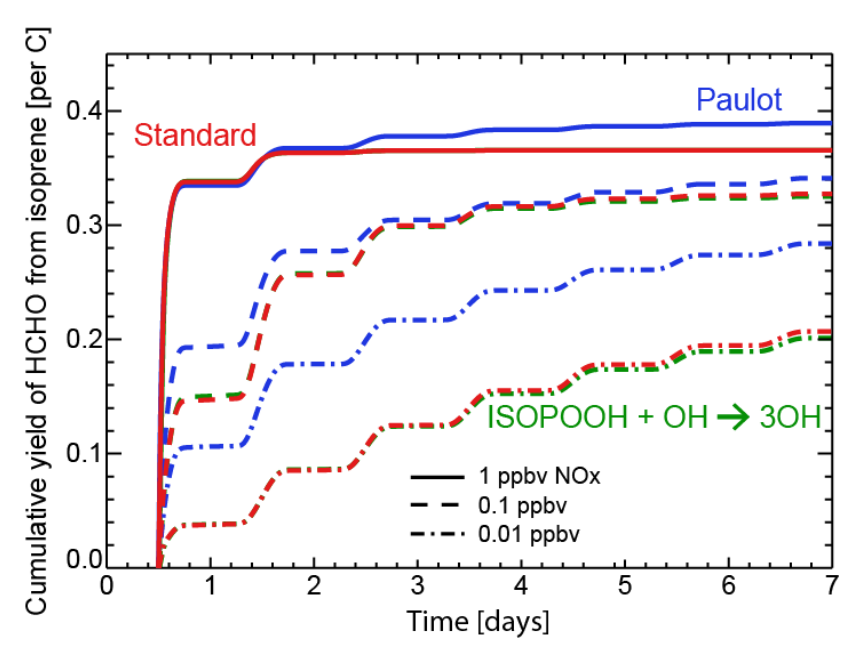

Fig. 4. Cumulative yields of $\mathrm{HCHO}$ per unit carbon from isoprene oxidation as a function of time in the DSMACC chemistry box model using the standard GEOS-Chem chemistry scheme (red), the Paulot scheme (blue), and the standard scheme with artificial generation of $\mathrm{OH}$ from isoprene hydroperoxide (ISOPOOH) oxidation (green) for different $\mathrm{NO}_{\mathrm{x}}$ levels initialized at local noon. Details on the box model simulation are given in the text.

isoprene-HCHO relationship will be discussed further in Sect. 4 in the context of GEOS-Chem results and using OMI $\mathrm{NO}_{2}$ columns to identify $\mathrm{NO}_{\mathrm{x}}$ regimes.

Also shown in Fig. 4 are box model results for the standard scheme including artificial $\mathrm{OH}$ generation from oxidation of ISOPOOH to prevent $\mathrm{OH}$ titration (Lelieveld et al., 2008). We find that this has almost no effect on the HCHO timedependent yield. The reason is that $\mathrm{HCHO}$ formation by the low- $\mathrm{NO}_{\mathrm{x}}$ channel involving ISOPOOH is limited in the standard scheme by the slow rate of ISOPOOH photolysis (lifetime of 8 days during daylight hours under box model conditions). Attack of ISOPOOH by OH in the standard scheme is assumed to take place mainly at the peroxide $\mathrm{H}$ and thus regenerate the peroxy radical ISOPOO. In the Paulot scheme, this attack results instead in the formation of epoxydiols, with a different $\mathrm{HCHO}$ yield as shown in Fig. 4.

\subsection{MEGAN Bottom-Up Isoprene Emission Inventory}

We use the MEGAN algorithm of Guenther et al. (2006) as our best prior emission estimate for isoprene to which the constraints from the OMI HCHO data can be compared. This inventory is widely used in global CTMs. Isoprene accounts for $80 \%$ of biogenic NMVOC emissions on a per-carbon basis in Africa according to MEGAN. The canopy-scale isoprene emission flux, $E_{\mathrm{ISOP}}$, per unit area of Earth surface (atoms $\mathrm{C} \mathrm{cm}^{-2} \mathrm{~s}^{-1}$ ) is computed as:

$E_{\mathrm{ISOP}}=E_{0} \gamma_{T} \gamma_{\mathrm{AGE}} \gamma_{\mathrm{SM}} \gamma_{\mathrm{CE}}$

Here $E_{0}$ is the emission at baseline conditions of air temperature $(303 \mathrm{~K})$, leaf age $(80 \%$ mature, $10 \%$ growing, and $10 \%$ old), soil moisture $\left(0.3 \mathrm{~m}^{3}\right.$ water $\mathrm{m}^{-3}$ soil), light $\left(1500 \mu \mathrm{mol}\right.$ photons $\left.\mathrm{m}^{-2} \mathrm{~s}^{-1}\right)$, and leaf area index $(\mathrm{LAI}=5)$. The dimensionless environmental scaling factors $(\gamma)$ describe the effects of temperature $(T)$, leaf age (AGE), soil moisture (SM), and canopy radiative environment (CE) on $E_{0} \cdot \gamma_{\mathrm{CE}}$ includes the effects of both LAI and light. Values of $E_{0}$ are specified for five plant functional types (PFTs): broadleaf trees, needleleaf trees, grasses, crops, and shrubs. The global distribution of PFTs is taken from the biome database of Olson et al. (2001), and the distribution of trees in Africa south of the Equator is overwritten by the regional database of Otter et al. (2003).

We apply the environmental scaling factors $\gamma$ as given by Guenther et al. (2006) to the local GEOS-5 environment, except for soil moisture. Stavrakou et al. (2009b) found in their analysis of GOME and SCIAMACHY HCHO satellite data that water stress has a major effect on isoprene emissions over southern Africa and is not well represented in MEGAN. We use here the soil moisture parameterization from Guenther et al. (2006) modified by Müller et al. (2008) and found by Ferreira et al. (2010) to achieve a good simulation of isoprene emission over West Africa during AMMA:

$\gamma_{\mathrm{SM}}=\sum_{i=1}^{n}\left[f_{i} \times \max \left(0, \min \left(1, \frac{\left(\theta_{i}-\theta_{i, \mathrm{w}}\right)}{0.06}\right)\right)\right]$

where the summation is over $n$ vertical soil layers, $f_{i}$ is the root fraction within soil layer $i$ such that $\sum_{i=1}^{n} f_{i}=1, \theta_{i}$ is the degree of saturation or volumetric ratio of soil moisture to the porosity of soil ( $\mathrm{m}^{3}$ water $\mathrm{m}^{-3}$ air), and $\theta_{i, \mathrm{w}}$ is the degree of saturation at the wilting point. The GEOS-5 meteorological data provide $\theta_{i}$ for two layers $(n=2)$ : a top soil layer $(2 \mathrm{~cm})$ and a root zone layer $(1 \mathrm{~m})$. Müller et al. (2008) used a fixed wilting point value of 0.171 , but here we use gridded monthly average wilting points, ranging from 0.05 to 0.6 in Africa, from the GEOS-5 catchment land surface model (Koster et al., 2000). We determine $f_{i}$ within each layer using the parameterization of Zeng (2001) applied to MODIS IGBP landcover (Friedl et al., 2002).

Our resulting global emission of isoprene in GEOS-Chem for 2006 is $470 \mathrm{Tg} \mathrm{Ca}^{-1}$, within the $440-660 \mathrm{Tg} \mathrm{C} \mathrm{a}^{-1}$ range given by Guenther et al. (2006). Africa accounts for $20 \%$ of global isoprene emissions. Implementation of the soil moisture scaling factor $\gamma_{\mathrm{SM}}$ as described above reduces annual isoprene emissions by about $10 \%$ globally and $15 \%$ over Africa. The global reduction in isoprene emissions is less than the $20 \%$ reduction obtained by Müller et al. (2008), likely due to the spatially variable wilting points used here.

\section{HCHO-isoprene relationship}

Previous interpretation of the $\mathrm{HCHO}$ column $\Omega_{\mathrm{HCHO}}$ in terms of above-canopy isoprene emission using GEOSChem has relied on a local linear regression between the two 

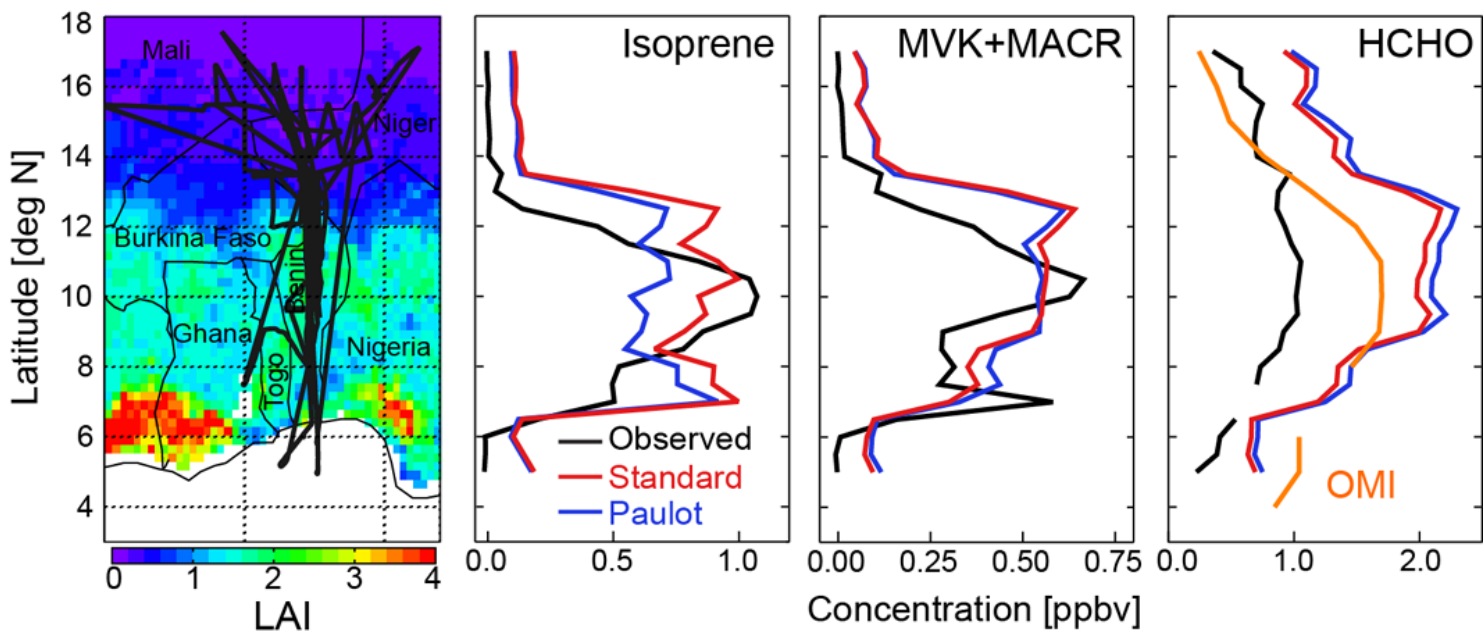

Fig. 5. Mean latitudinal gradients of boundary layer $(<1 \mathrm{~km})$ isoprene, MVK + MACR, and HCHO concentrations during the AMMA aircraft campaign in July-August 2006. The left panel shows the AMMA flight tracks superimposed on a map of MODIS leaf area index (LAI) (Yang et al., 2006) for the AMMA period. Observations averaged over $0.5^{\circ}$ latitudinal bins are shown in black. Model results sampled along the flight tracks and at the flight times are shown in red (standard GEOS-Chem isoprene oxidation scheme) and in blue (Paulot scheme). Mean OMI HCHO averaged over $1^{\circ}$ latitude bins for July-August 2005-2009 is shown in orange (see text).

quantities in the model (Palmer et al., 2003):

$\Omega_{\mathrm{HCHO}}=S E_{\mathrm{ISOP}}+B$

where $S$ is the slope of the reduced-major-axis regression line and $B$ is the intercept representing the background $\mathrm{HCHO}$ column. The value of $S$ is determined by the $\mathrm{HCHO}$ yield from isoprene oxidation and by the HCHO lifetime. Millet et al. (2008) presented estimates of $S$ for North America in summer by performing either a single regression for the ensemble of GEOS-Chem gridsquares covering North America or local regressions for individual $2 \times 2.5^{\circ}$ gridsquares. The first method yielded $S=2.4 \times 10^{3}$ s with high correlation $\left(R^{2}=0.82\right)$, while the second yielded variable slopes with an interquartile range of $2.0-3.0 \times 10^{3} \mathrm{~s}$. These values were consistent with observation-based estimates for the PROPHET forest site in Michigan $\left(2.1 \times 10^{3} \mathrm{~s}\right)$ and INTEXA aircraft observations over the eastern US $\left(2.3 \times 10^{3} \mathrm{~s}\right)$ (Palmer et al., 2003; Millet et al., 2006). Over tropical South America where $\mathrm{NO}_{\mathrm{x}}$ levels are much lower, Barkley et al. (2008) found a strong spatial correlation $\left(R^{2}>0.7\right)$ between $E_{\mathrm{ISOP}}$ and $\Omega_{\mathrm{HCHO}}$ in GEOS-Chem but with large seasonal variability in $S$ - ranging from $1.2 \times 10^{3} \mathrm{~s}$ in JanuaryMarch to $2.2 \times 10^{3} \mathrm{~s}$ in May-July.

Here we use our updated version of GEOS-Chem, together with observational constraints from AMMA and OMI, to examine the local $E_{\mathrm{ISOP}}-\Omega_{\mathrm{HCHO}}$ relationships over Africa and their suitability for inferring isoprene emissions from the $\mathrm{HCHO}$ column data. We quantify smearing of the relationship caused by delay in $\mathrm{HCHO}$ production from isoprene, develop a parameterization for the dependence of the $E_{\mathrm{ISOP}^{-}}$ $\Omega_{\mathrm{HCHO}}$ relationship on $\mathrm{NO}_{\mathrm{x}}$, and estimate errors in the resulting isoprene emission estimates.

\subsection{Smearing}

We first examine the extent of smearing in the HCHOisoprene relationship over Africa using aircraft measurements of isoprene, the sum of MVK and MACR (MVK + MACR), and HCHO concentrations obtained during AMMA in West Africa in July-August 2006 (Murphy et al., 2010; Reeves et al., 2010). The AMMA wet season aircraft campaign (Redelsperger et al., 2006), based in Niamey, Niger, made latitudinal transects across sharp vegetation gradients from ocean to dense woodland to desert (Fig. 5). 19 flights were conducted, mainly during daytime hours. Boundary layer winds were prevailingly from the south (West African monsoon) (Janicot et al., 2008). We exclude biomass burning plumes as diagnosed by $>250 \mathrm{pptv}$ acetonitrile (Commane et al., 2010; Murphy et al., 2010) as well as the flights of 8 August (Lagos urban plume) and 15 August (mesoscale convective system).

Figure 5 shows the AMMA flight tracks superimposed on a map of MODIS LAI for July-August 2006 (Yang et al., 2006), together with latitudinal mean profiles of observed and simulated isoprene, MVK + MACR, and HCHO concentrations below $1 \mathrm{~km}$ altitude. The model is sampled along the flight tracks and at the flight times. Also included in Fig. 5 is the HCHO concentration below $1 \mathrm{~km}$ inferred from OMI observations for July-August 2005-2009 averaged over the AMMA longitudinal domain $\left(1-4^{\circ} \mathrm{E}\right)$ into $1^{\circ}$ latitude bins (multi-year temporal averaging is needed to reduce measurement noise). The HCHO concentration below $1 \mathrm{~km}$ is inferred from OMI HCHO columns by using the mean $\mathrm{HCHO}$ vertical profile measured during AMMA ( 340 pptv above $2 \mathrm{~km}$ and linear increase from $2 \mathrm{~km}$ down to the surface). 
The break in the OMI data at $5-7^{\circ} \mathrm{N}$ reflects the exclusion of anthropogenic influence from Nigeria (Sect. 2.2). Boundary layer $(<1 \mathrm{~km}) \mathrm{NO}_{\mathrm{x}}$ concentrations in the region of isoprene emission $\left(7-13^{\circ} \mathrm{N}\right)$ averaged $360 \mathrm{pptv}$ in the observations and $310 \mathrm{pptv}$ in the model, reflecting a mix of influences from soil, anthropogenic, and distant biomass burning sources (Stewart et al., 2008; Hopkins et al., 2009; Reeves et al., 2010).

The sharp vegetation gradients sampled in AMMA along the direction of the prevailing southerly monsoon winds make the data of great value for understanding smearing in the HCHO-isoprene relationship. We see from Fig. 5 that observed isoprene and MVK + MACR tightly follow the vegetation gradients and this is well captured by the model. Model values are much higher than observed at $11-13^{\circ} \mathrm{N}$ and $7-$ $8^{\circ} \mathrm{N}$, reflecting a local overestimate of $E_{\text {ISOP }}$ in MEGAN (Ferreira et al., 2010; Murphy et al., 2010). MVK and MACR are first-stage $\mathrm{C}_{4}$ isoprene oxidation products, with $\mathrm{HCHO}$ produced from the additional carbon atom (Paulson et al., 1992). The tightness of the isoprene-(MVK + MACR) relationship in Fig. 5, both in the observations and the model, demonstrates that there is no significant smearing of these species and provides an important test of the isoprene oxidation scheme. Model isoprene concentrations are lower in the Paulot scheme because of $\mathrm{OH}$ regeneration from the ISOPOO $+\mathrm{HO}_{2}$ reaction pathway, as described in Sect. 3.2, but this has negligible impact on the simulation of (MVK + MACR).

The far right panel of Fig. 5 shows that observed and simulated HCHO are also strongly correlated with the vegetation gradients. The AMMA observations for $\mathrm{HCHO}$ are much lower than the model or inferred from OMI, and we do not have an explanation for this beyond the possibility of large bias in the Hantzsch-fluorometric instrument used on the aircraft (Hak et al., 2005, and references therein). Because HCHO is produced together with MVK + MACR and this first-stage production accounts for $80-90 \%$ of the ultimate $\mathrm{HCHO}$ yield under the AMMA conditions (see below), it would be difficult to account for a model bias in HCHO but not in MVK + MACR. Tests with the model indicate little sensitivity to the assumed deposition velocities. In any case, comparison of the $\mathrm{HCHO}$ and isoprene latitudinal gradients shows no significant northward smearing either in the observations or the model. Correlation between observed isoprene and $\mathrm{HCHO}$ is strongest $\left(R^{2}=0.86\right)$ for a $0.5^{\circ}$ northward shift of $\mathrm{HCHO}$ relative to isoprene. Smearing of $\sim 0.5^{\circ}$, combined with a mean observed southerly wind speed of $17 \mathrm{~km} \mathrm{~h}^{-1}$ south of $12^{\circ} \mathrm{N}$, implies a timescale of less than a day for production of $\mathrm{HCHO}$ from isoprene.

The negligible smearing in the AMMA observations may reflect the relatively high $\mathrm{NO}_{\mathrm{x}}$ conditions and low levels of isoprene, promoting loss of the ISOPOO radicals by reaction with $\mathrm{NO}$ which results in fast $\mathrm{HCHO}$ production (high- $\mathrm{NO}_{\mathrm{x}}$ pathway). Figure 6 shows the simulated fraction of ISOPOO radicals reacting with NO across Africa in July 2006 (Paulot

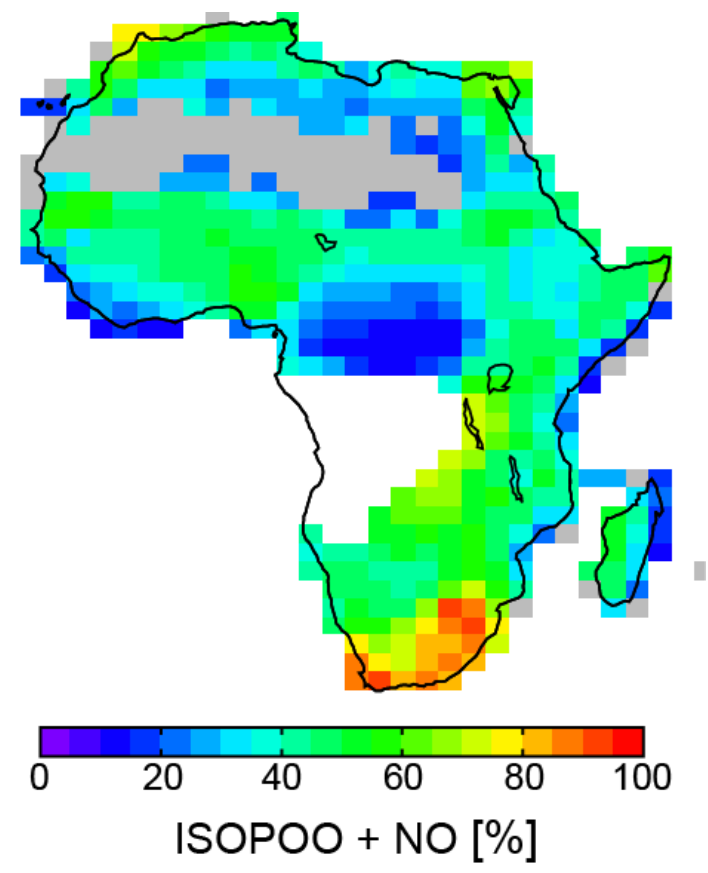

Fig. 6. Percentage of isoprene peroxy radicals (ISOPOO) reacting with NO in the GEOS-Chem simulation for July 2006 using the Paulot scheme for isoprene chemistry. Values are computed from monthly mean reaction rates. Grey gridsquares have zero isoprene emissions in GEOS-Chem and white gridsquares are screened because of biomass burning influence.

scheme). For the AMMA region that fraction is $\sim 50 \%$. Stone et al. (2010) previously found a $70 \%$ mean fraction during AMMA using the DSMACC box model constrained by the NO observations.

The OMI $\mathrm{NO}_{2}$ data offer a broad perspective on $\mathrm{NO}_{\mathrm{x}}$ regimes across Africa. Figure 7 shows annual average tropospheric columns of $\mathrm{NO}_{2}\left(\Omega_{\mathrm{NO}_{2}}\right)$ from OMI (Boersma et al., 2007) for 2005-2009 and compares to the GEOSChem simulation for 2006. Biomass burning influence has been removed in the observations using MODIS fire counts and OMI AAOD (Sect. 2.2) and in GEOS-Chem with black carbon AOD from the model, for consistency with the removal of biomass burning influence in the OMI $\mathrm{HCHO}$ column product. Assuming a linear decrease of $\mathrm{NO}_{2}$ mixing ratio from the surface to $3 \mathrm{~km}$ with negligible $\mathrm{NO}_{2}$ above, based on the AMMA observations (Stewart et al., 2008), we can make a rough estimate of the boundary layer $(<1 \mathrm{~km}) \mathrm{NO}_{\mathrm{x}}$ concentration from the OMI $\mathrm{NO}_{2}$ data and this is also shown in Figure 7. Thus $1 \mathrm{ppbv}$ of boundary layer $\mathrm{NO}_{\mathrm{x}}$ corresponds roughly to a tropospheric $\mathrm{NO}_{2}$ column of $2 \times 10^{15}$ molecules $\mathrm{cm}^{-2}$. The fitting precision of $7-8 \times 10^{14}$ molecules $\mathrm{cm}^{-2}$ for individual $\mathrm{OMI} \mathrm{NO}_{2}$ pixels (Boersma et al., 2007) is reduced to 3$4 \times 10^{13}$ molecules $\mathrm{cm}^{-2}$ for monthly mean data at $1^{\circ} \times 1^{\circ}$ resolution, so that levels as low as $\sim 0.02 \mathrm{ppbv} \mathrm{NO}_{\mathrm{x}}$ are 


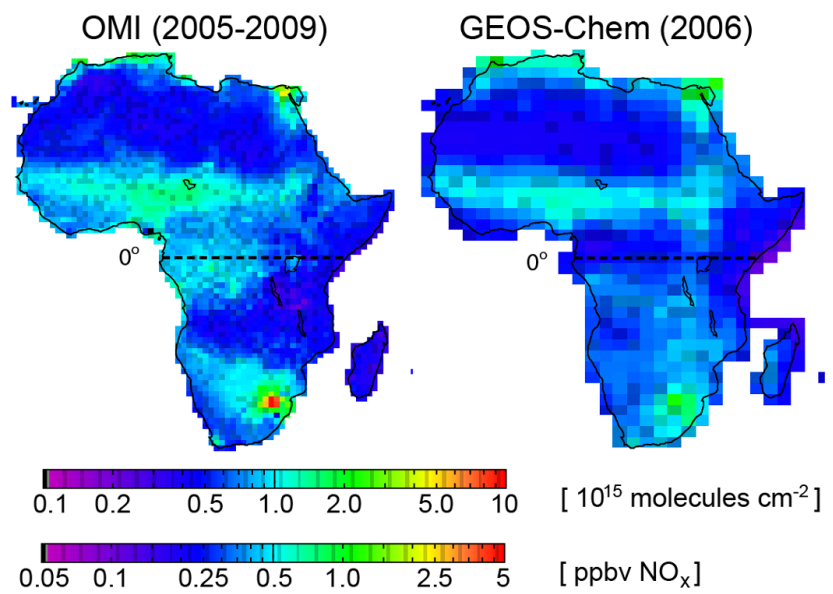

Fig. 7. Annual mean tropospheric $\mathrm{NO}_{2}$ columns over Africa at 12:00-15:00 LT. The left panel shows OMI 2005-2009 data at $1 \times 1^{\circ}$ resolution (Boersma et al., 2007). The right panel shows GEOS-Chem model values for 2006. The colorbar includes boundary layer $(<1 \mathrm{~km}) \mathrm{NO}_{\mathrm{x}}$ estimated from column $\mathrm{NO}_{2}$ (see text for details). Biomass burning influence was removed using MODIS fire counts and OMI smoke AAOD in the observations, and black carbon AOD in GEOS-Chem. The equator is indicated.

detectable. We see in Fig. 7 that much of Africa is in an intermediate $\mathrm{NO}_{\mathrm{x}}$ regime $(0.1-1 \mathrm{ppbv})$. Even in the absence of continental biomass burning influences, significant boundary layer $\mathrm{NO}_{\mathrm{x}}$ levels are maintained in Africa by soil emissions (Jaeglé et al., 2005) and by decomposition of peroxyacetylnitrate (PAN) originating from outside the continent (Singh and Hanst, 1981; Moore and Remedios, 2010).

Inspection of Fig. 6 suggests that the equatorial rainforest, where isoprene emissions are very high, could be particularly sensitive to the expected smearing of the HCHO-isoprene relationship. There the model fraction of ISOPOO radicals reacting with NO is only $15 \%$, even though boundary layer $\mathrm{NO}_{\mathrm{x}}$ is not particularly low ( 300 pptv; Fig. 7). That region is ventilated by a steady easterly wind so that a longitudinal transect can reveal smearing. Figure 8 shows the longitudinal gradients of MEGAN $E_{\text {ISOP }}$, OMI $\Omega_{\mathrm{HCHO}}$, and model column $\mathrm{HCHO}$ (standard and Paulot schemes) across the region at $0-3^{\circ} \mathrm{N}$ for gridsquares not influenced by biomass burning. Immediately downwind (to the west) of the rainforest is a shadow region where elevated HCHO does not correspond to collocated isoprene emission. The shadow region is well reproduced by the model using either the standard or Paulot scheme. Assuming that MEGAN correctly represents the location of isoprene emission (mainly determined by the location of the equatorial rainforest), enhancements in OMI $\Omega_{\mathrm{HCHO}}$ are sustained $\sim 2-3^{\circ}$ west of that location. Combined with a mean easterly wind speed of $5 \mathrm{~km} \mathrm{~h}^{-1}$ this implies a timescale of $\sim 2-3$ days for production of $\mathrm{HCHO}$ from isoprene, consistent with Fig. 4. We will see below how

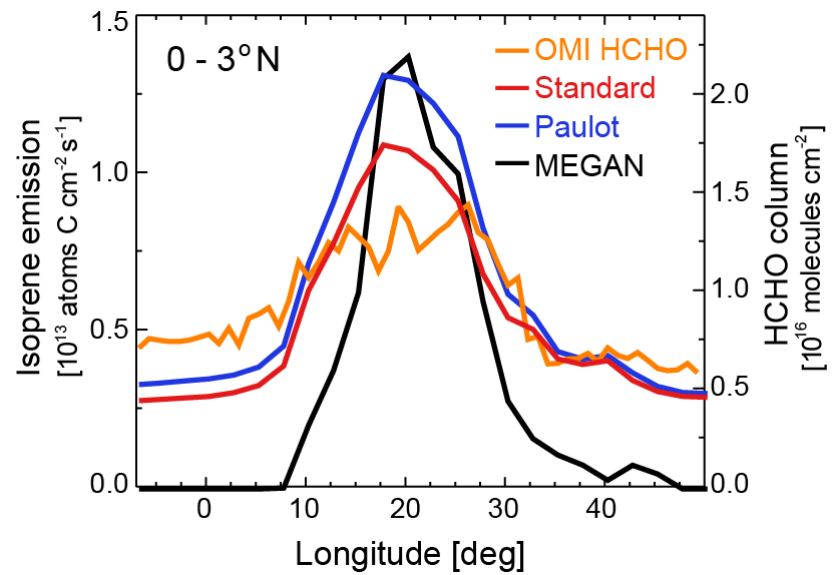

Fig. 8. Mean longitudinal gradients of isoprene emission (black) and $\mathrm{HCHO}$ columns (color) across central Africa $\left(0-3^{\circ} \mathrm{N}\right)$ at 12:00-15:00 LT in July. HCHO columns are shown for the OMI observations in 2005-2009 (orange) and from the GEOS-Chem simulations using the standard isoprene oxidation scheme (red) and the Paulot scheme (blue) in 2006. Isoprene emissions are from MEGAN. The HCHO columns have been filtered against biomass burning as described in the text.

we can screen such shadow regions when inferring isoprene emissions from the OMI HCHO data.

\section{2 $\mathrm{NO}_{\mathrm{x}}$ dependence}

We now examine the variability of the $\Omega_{\mathrm{HCHO}}-E_{\mathrm{ISOP}}$ relationship over Africa in GEOS-Chem measured by the local slope $S$ in Eq. (1). This variability reflects differences in the chemical environment as well as the effect of smearing in an inhomogeneous isoprene emission field. Millet et al. (2008) previously examined the spatial variability of $S$ over North America by constructing local $\Omega_{\mathrm{HCHO}}-E_{\mathrm{ISOP}}$ regressions at the $2 \times 2.5^{\circ}$ grid resolution of GEOS-Chem, relying on the temperature-driven day-to-day variation of $E_{\mathrm{ISOP}}$ in a given gridsquare to define a dynamic range for the regression. We find that this is not an effective approach in Africa as day-today variability in isoprene emission is often small. We derive instead the $\Omega_{\mathrm{HCHO}}-E_{\mathrm{ISOP}}$ relationship in GEOS-Chem by conducting a sensitivity simulation with isoprene emissions reduced by a factor of 2 from the MEGAN values. We then infer $S=\Delta \Omega_{\mathrm{HCHO}} / \Delta E_{\mathrm{ISOP}}$ for individual gridsquares and months (gridsquare-months) where $\Delta$ is the monthly mean 12:00-15:00 LT change relative to the standard simulation, excluding periods of biomass burning influence (diagnosed with black carbon AOD in the model). Values of $S$ over the southeast US $\left(75-100^{\circ} \mathrm{W}, 27-40^{\circ} \mathrm{N}\right)$ for June-August 2006 using this approach are 1.9 and $2.0 \times 10^{3} \mathrm{~s}$ for the standard and Paulot schemes, respectively, similar to values reported by Millet et al. $(2006,2008)$ and Palmer et al. (2006).

We find that $41 \%$ of gridsquare-months in GEOS-Chem over Africa have $S>4 \times 10^{3} \mathrm{~s}$, which is higher than $\mathrm{HCHO}$ 
yields from isoprene emission would allow. This reflects smearing as diagnosed in the model and mainly affects regions where isoprene emissions are very low (such as the vast desert expanses as well as coastal gridsquares). We exclude this population from further analysis; although this may seem like a large population to exclude, the corresponding area accounts for only $2 \%$ of isoprene emission over Africa in MEGAN and thus is largely irrelevant for our purpose.

For the remainder of the data we find a significant dependence of $S$ on the local $\mathrm{NO}_{\mathrm{x}}$ concentration, as would be expected from our box model results in Fig. 4. We choose to define this relationship in the model in terms of $S$ vs. $\Omega_{\mathrm{NO}_{2}}$ so that the OMI $\Omega_{\mathrm{NO}_{2}}$ data can be applied to remove the effects of model errors in $\mathrm{NO}_{\mathrm{x}}$. Figure 9 shows the $S$ values calculated for individual $2 \times 2.5^{\circ}$ gridsquare-months over the African continent in 2006 as a function of local model $\Omega_{\mathrm{NO}_{2}}$. The data are averaged into $1 \times 10^{14}$ molecules $\mathrm{NO}_{2} \mathrm{~cm}^{-2}$ bins. For $\Omega_{\mathrm{NO}_{2}} \leq 1 \times 10^{15}$ molecules $\mathrm{cm}^{-2}$ (roughly 0.5 ppbv boundary layer $\mathrm{NO}_{\mathrm{x}}$ using our conversion factor) we find a linear relationship between $S$ and $\Omega_{\mathrm{NO}_{2}}\left(R^{2}>0.9\right)$ reflecting the increasing importance of the $\mathrm{RO}_{2}+\mathrm{NO}$ pathway with increasing $\mathrm{NO}_{\mathrm{x}}$. For $\Omega_{\mathrm{NO}_{2}}>1 \times 10^{15}$ molecules $\mathrm{cm}^{-2}$ we find that $S$ levels off as the $\mathrm{RO}_{2}+\mathrm{NO}$ pathway becomes dominant. 10-20\% higher HCHO yields in the Paulot scheme compared with the standard scheme are consistent with the box model results of Fig. 4.

\subsection{Error analysis}

Inference of isoprene emission from OMI column $\mathrm{HCHO}$ involves a number of steps, all of which are prone to error. Here we estimate these different error terms and their contributions to the overall error.

The spectral fitting uncertainty for $\Omega_{\mathrm{s}}$ observations averaged over $1 \times 1^{\circ}$ gridsquares and 8 -day periods is 1 $2 \times 10^{15}$ molecules $\mathrm{cm}^{-2}$ (Sect. 2.1). We find (not shown) that the model can reproduce the shape of the mean $\mathrm{HCHO}$ vertical profile observed in AMMA (linear decrease from the surface to $2 \mathrm{~km}$, low values above $2 \mathrm{~km}$ ), consistent with previous results for North America (Palmer et al., 2003; Millet et al., 2006), and suggesting that there is no particular problem in simulating the $\mathrm{HCHO}$ vertical shape factor under African conditions. We adopt the AMF error estimate of Millet et al. (2006) derived from aircraft observations in North America: $15 \%$ for clear sky increasing to $24 \%$ for $50 \%$ cloud cover (Millet et al., 2006). Taking a fitting error of $2 \times 10^{15}$ molecules $\mathrm{cm}^{-2}$ and an AMF error of $20 \%$ (since we exclude scenes with $>40 \%$ cloud cover), and applying these errors in quadrature to a vertical $\mathrm{HCHO}$ column of $1 \times 10^{16}$ molecules $\mathrm{cm}^{-2}$ with AMF of 1.2 , we estimate an overall error on the OMI HCHO retrieval of $2 \times 10^{15}$ molecules $\mathrm{cm}^{-2}$ or $20 \%$.

Conversion of $\mathrm{HCHO}$ columns to isoprene emission using Eq. (1) involves errors in the slope $S$ due both to the chemical

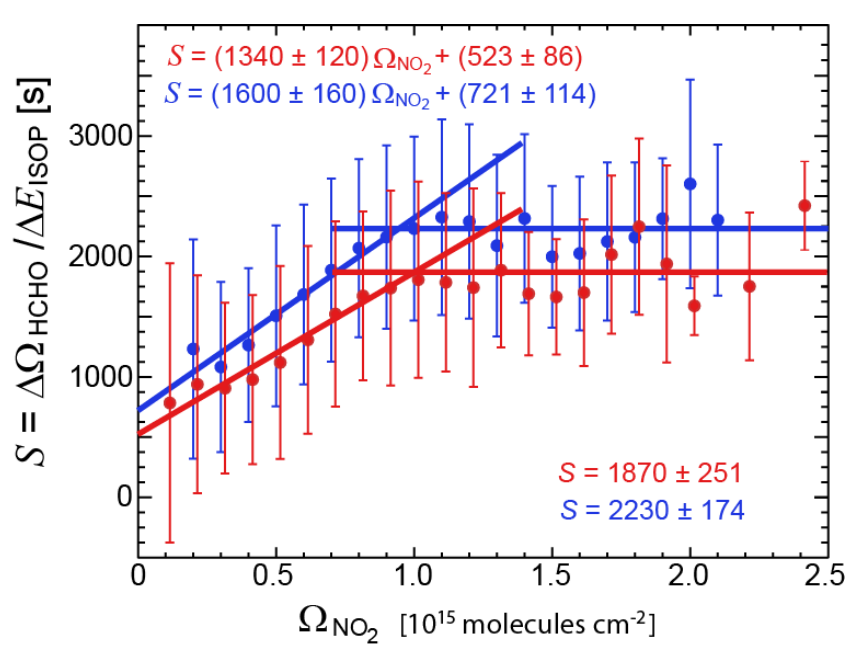

Fig. 9. Dependence of the HCHO-isoprene relationship on the local tropospheric $\mathrm{NO}_{2}$ column $\Omega_{\mathrm{NO}_{2}}$ over Africa in GEOS-Chem. The figure shows statistics of $S=\Delta \Omega_{\mathrm{HCHO}} / \Delta E_{\mathrm{ISOP}}$ computed as described in the text for individual $2 \times 2.5^{\circ}$ gridsquares and months in 2006 at 12:00-15:00 LT. Values of $S$ have been sorted by the local value of $\Omega_{\mathrm{NO}_{2}}$ in $1 \times 10^{14}$ molecules $\mathrm{cm}^{-2}$ bins, and means and standard deviations are shown in each bin for GEOS-Chem using the standard isoprene oxidation scheme (red) and the Paulot scheme (blue). The data for $\Omega_{\mathrm{NO}_{2}} \leq 1 \times 10^{15}$ molecules $\mathrm{cm}^{-2}$ show a linear relationship between $S$ and $\Omega_{\mathrm{NO}_{2}}$, and reduced-major-axis regression parameters are shown inset with standard deviations determined using jackknife resampling (Manly, 1997). The data for $\Omega_{\mathrm{NO}_{2}}>1 \times 10^{15}$ molecules $\mathrm{cm}^{-2}$ show no significant dependence between $S$ and $\Omega_{\mathrm{NO}_{2}}$, and the corresponding mean values and standard deviations of $S$ are shown inset.

mechanism and to smearing. Figure 9 shows that the standard and Paulot mechanisms differ by only $15 \%$ in their calculations of $S$, which is similar to the error estimates from Palmer et al. (2006) and Millet et al. (2008) in comparing $S$ values from GEOS-Chem to aircraft and surface observations over the US. The error is certainly larger under low- $\mathrm{NO}_{\mathrm{x}}$ conditions where better understanding of low- $\mathrm{NO}_{\mathrm{x}}$ yields of HCHO is needed. The error bars on $S$ shown in Fig. 9 (which we attribute mainly to smearing) are larger than errors induced by the chemical mechanism. From these error bars we derive a smearing uncertainty in $S$ of 750 s for the low- $\mathrm{NO}_{\mathrm{x}}$ regime $\left(\Omega_{\mathrm{NO}_{2}}=0.2-1 \times 10^{15}\right.$ molecules cm$\left.{ }^{-2}\right)$ and $690 \mathrm{~s}$ for the high- $\mathrm{NO}_{\mathrm{x}}$ regime $\left(\Omega_{\mathrm{NO}_{2}}>1 \times 10^{15}\right.$ molecules $\left.\mathrm{cm}^{-2}\right)$.

Error in the OMI tropospheric $\mathrm{NO}_{2}$ column also propagates to error in the linear regression equation $S=\left(1600 \pm 160 \times 10^{-15}\right) \Omega_{\mathrm{NO}_{2}}+(721 \pm 114)$ for the low$\mathrm{NO}_{\mathrm{x}}$ regime (Paulot scheme in Fig. 9). We use the expression from Boersma et al. (2008) to estimate the error standard deviation $\sigma_{\mathrm{NO}_{2}}\left(\right.$ molecules $\mathrm{cm}^{-2}$ ) for 8-day average $\Omega_{\mathrm{NO}_{2}}$ observations:

$\sigma_{\mathrm{NO}_{2}}=\frac{1.0 \times 10^{15}+0.3 \times \Omega_{\mathrm{NO}_{2}}}{\sqrt{8} \times \sqrt{3.5}}$ 
and propagate this with the linear regression errors in the slope $m\left(\sigma_{\mathrm{m}}=160 \times 10^{-15} \mathrm{~s} \mathrm{~cm}^{2}\right.$ molecule $\left.^{-1}\right)$ and intercept $c\left(\sigma_{\mathrm{c}}=114 \mathrm{~s}\right)$. The resulting error standard deviation $\sigma_{\mathrm{S}}$ in $S$ is $\sigma_{\mathrm{S}}=\sqrt{\left(m \times \sigma_{\mathrm{NO}_{2}}\right)^{2}+\left(\Omega_{\mathrm{NO}_{2}} \times \sigma_{\mathrm{m}}\right)^{2}+\sigma_{\mathrm{c}}^{2}}$ and is in the range $340-440 \mathrm{~s}$ for $\Omega_{\mathrm{NO}_{2}}$ of $0.2-$ $1.0 \times 10^{15}$ molecules $\mathrm{cm}^{-2}$; smaller than the estimated smearing error of $750 \mathrm{~s}$. The error in $S$ at low $\mathrm{NO}_{\mathrm{x}}$, adding in quadrature the contributions from smearing and from the linear regression, is $823-870 \mathrm{~s}(35-84 \%)$.

The overall error in inferring isoprene emission from OMI $\mathrm{HCHO}$ columns, adding in quadrature the errors in the OMI retrieval of $\mathrm{HCHO}$ columns and the conversion of $\mathrm{HCHO}$ columns to isoprene emission, is $40 \%$ in the high- $\mathrm{NO}_{\mathrm{x}}$ regime and $40-90 \%$ in the low- $\mathrm{NO}_{\mathrm{x}}$ regime. These errors apply to 8 -day average $1 \times 1^{\circ} \mathrm{OMI} \mathrm{HCHO}$ data and could be reduced by further temporal averaging to the extent that they are random, which is difficult to assess given the uncertainties associated with the isoprene oxidation mechanism at low levels of $\mathrm{NO}_{\mathrm{x}}$.

\section{Implications for OMI-derived isoprene emissions in Africa}

We have presented here a new methodology for inferring isoprene emissions from $\mathrm{HCHO}$ satellite data and applied it to the African continent using OMI. Detailed discussion of the implications for African isoprene emissions and their dependence on environmental variables is left to a separate paper. We present here some preliminary results. For this purpose we use the 2005-2009 monthly mean OMI HCHO vertical columns at $1 \times 1^{\circ}$ horizontal resolution derived in Sect. 2, monthly mean $S$ values computed from GEOS-Chem with the Paulot scheme, and 2005-2009 monthly mean $\mathrm{NO}_{2}$ tropospheric column observations from OMI (Boersma et al., 2007).

Figure 10 shows the resulting spatial distribution of annual above-canopy isoprene emissions at 12:00-15:00 LT and compares with the corresponding values from the MEGAN inventory. Values are means for all $1 \times 1^{\circ}$ gridsquare-months that are not excluded from our analysis because of biomass burning, anthropogenic, dust, or smearing influences. Fully excluded areas are shown in grey. The right panel shows the difference between the OMI-derived emissions and values from MEGAN.

From the data in Fig. 10 we find that the annual mean isoprene emissions in Africa inferred from OMI $\left(60 \mathrm{Tg} \mathrm{C} \mathrm{a}^{-1}\right)$ are on average $22 \%$ lower than the MEGAN values $\left(77 \mathrm{Tg} \mathrm{Ca}^{-1}\right)$. Some larger regional discrepancies are apparent. Maximum isoprene emissions in central Africa are displaced north in MEGAN relative to OMI, and OMI is on average $43 \%$ lower than MEGAN over the central African rainforest, and $21 \%$ higher over the southern deciduous broadleaf forests. The discrepancy in central Africa increases to $53 \%$ if scenes with $>40 \%$ cloud cover are excluded from the MEGAN emission inventory for consistency with the OMI screening threshold.

\section{Conclusions}

We presented a new method for inferring biogenic isoprene emissions from satellite observations of HCHO columns under the particularly challenging conditions of the tropics, and applied this method to 2005-2009 OMI HCHO observations over the African continent.

Removing biomass burning influence is critical for isolating the biogenic component of $\mathrm{HCHO}$ in the tropics. Previous procedures using satellite fire counts or $\mathrm{NO}_{2}$ columns are insufficient because they do not account for long-range transport of fire plumes. Here we used OMI observations of absorbing aerosol optical depth (AAOD) as an additional screening tool. We also identified a significant anthropogenic component over Africa associated with gas flaring, particularly in Nigeria, and removed it using small-flame satellite fire data. Our resulting biogenic HCHO product shows close correspondence with the distribution of vegetation in Africa.

Inferring isoprene emission from $\mathrm{HCHO}$ column data requires knowledge of the time-dependent $\mathrm{HCHO}$ yield from isoprene oxidation. This is a challenge in the tropics because of the prevailing low- $\mathrm{NO}_{\mathrm{x}}$ conditions under which the isoprene oxidation mechanism is not well understood and $\mathrm{HCHO}$ production may be delayed. Here we used two alternate mechanisms to quantify $\mathrm{HCHO}$-isoprene relationships in GEOS-Chem. The two mechanisms show a similar positive $\mathrm{NO}_{\mathrm{x}}$ dependence of the $\mathrm{HCHO}$ yield under low$\mathrm{NO}_{\mathrm{x}}$ conditions, and a delay between isoprene emission and $\mathrm{HCHO}$ production ranging from less than a day under high$\mathrm{NO}_{\mathrm{x}}$ conditions to several days under low- $\mathrm{NO}_{\mathrm{x}}$ conditions. This delay smears the local relationship between isoprene emission $\left(E_{\mathrm{ISOP}}\right)$ and $\mathrm{HCHO}$ columns $\left(\Omega_{\mathrm{HCHO}}\right)$.

We evaluated the GEOS-Chem simulation of the HCHOisoprene relationship using aircraft observations from the AMMA campaign along a latitudinal transect of vegetation types in West Africa. Both observations and model show strong spatial correlation between isoprene, MVK + MACR (first-stage products of isoprene oxidation associated with $\mathrm{HCHO}$ formation), and $\mathrm{HCHO}$. This implies insignificant $(<100 \mathrm{~km})$ smearing in the $\mathrm{HCHO}$-isoprene relationship. The conditions for isoprene oxidation in AMMA are intermediate between the low- $\mathrm{NO}_{\mathrm{x}}$ and high- $\mathrm{NO}_{\mathrm{x}}$ regimes, with $50 \%$ of isoprene peroxy radicals (ISOPOO) reacting with NO. Inspection of longitudinal gradients across the equatorial forest of central Africa, which is more strongly in the low- $\mathrm{NO}_{\mathrm{x}}$ regime (15\% of ISOPOO reacting with NO), indicates a smearing of $\sim 200-300 \mathrm{~km}$. This means that large isoprene source regions under low- $\mathrm{NO}_{\mathrm{x}}$ conditions produce a shadow effect downwind that affects interpretation of the local HCHO-isoprene relationship. 


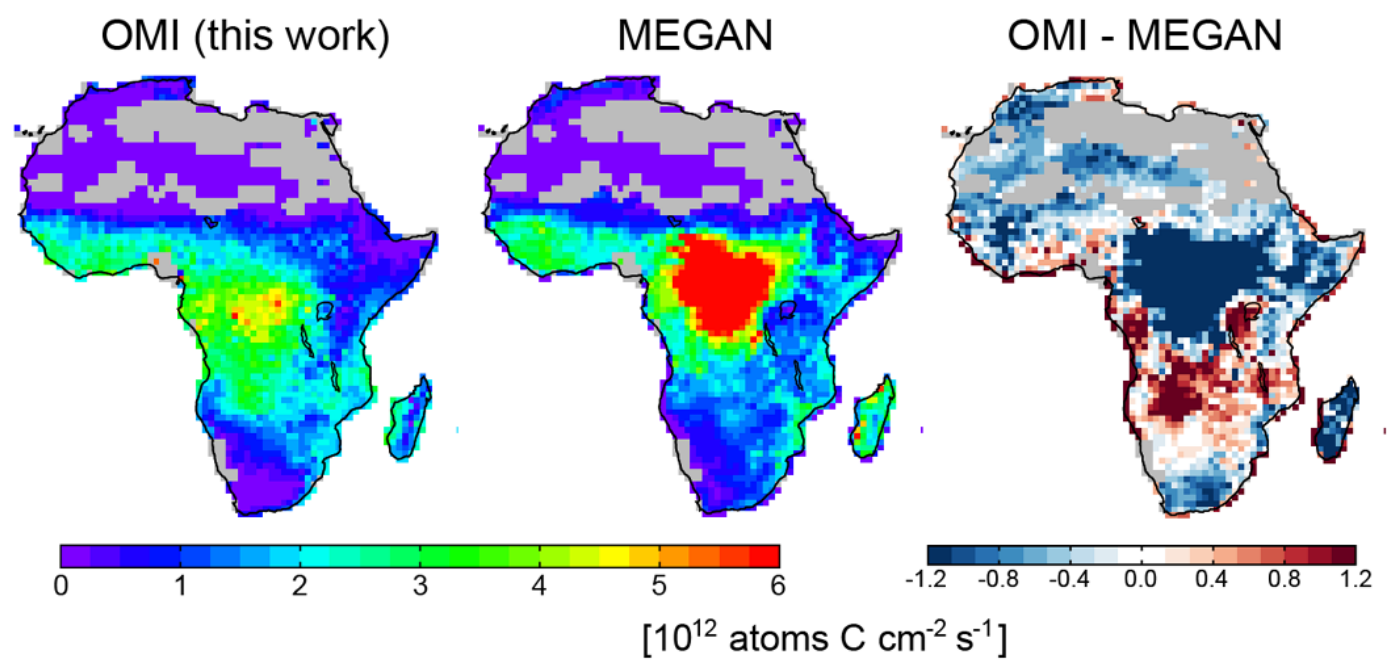

Fig. 10. Annual average isoprene emissions from Africa at $1 \times 1^{\circ}$ horizontal resolution at 12:00-15:00 LT. Values inferred from the OMI HCHO 2005-2009 data (left) are compared to values from the MEGAN bottom-up inventory (center). The right panel shows the difference between the two. Results are for the ensemble of $1 \times 1^{\circ}$ gridsquare-months that are not excluded from our analysis due to biomass burning, anthropogenic, dust, or smearing influences (see text). Completely excluded areas are shown in grey.

We computed local relationships between $\mathrm{HCHO}$ columns and isoprene emission at the $2 \times 2.5^{\circ}$ GEOS-Chem grid resolution and on a monthly basis by conducting a sensitivity simulation with uniformly perturbed isoprene emission and inferring the relationship $S=\Delta \Omega_{\mathrm{HCHO}} / \Delta E_{\text {ISOP. }}$. Smearing was diagnosed by anomalously high $S$ values and the corresponding scenes were excluded from further analysis. We found that $S$ is sensitive to $\mathrm{NO}_{\mathrm{x}}$ at levels below 500 pptv (tropospheric $\mathrm{NO}_{2}$ column $\leq 1 \times 10^{15}$ molecules $\mathrm{cm}^{-2}$ ). From there we used the $\mathrm{OMI} \mathrm{NO}_{2}$ column observations to diagnose $S$ for the corresponding OMI HCHO data. The estimated error in OMI-derived isoprene emissions is $40 \%$ at high $\mathrm{NO}_{\mathrm{x}}$ and $40-90 \%$ at low $\mathrm{NO}_{\mathrm{x}}$ for 8 -day averages with $1 \times 1^{\circ}$ resolution. Smearing makes the largest contribution to the estimated error for both $\mathrm{NO}_{\mathrm{x}}$ regimes.

We presented a preliminary comparison of the OMIderived annual mean isoprene emissions over Africa to the values computed from the bottom-up MEGAN inventory. The total OMI-derived isoprene emission for the African continent is $22 \%$ lower than MEGAN. Large regional discrepancies are apparent for the high-emitting evergreen broadleaf trees of central Africa and the southern hemisphere deciduous broadleaf trees. In a follow-up paper we will exploit the OMI HCHO data to develop improved understanding of the environmental, seasonal, and interannual variations in isoprene emission over Africa using the OMI HCHO observations.

The two main uncertainties in using space-based $\mathrm{HCHO}$ column data to infer isoprene emission are (1) the isoprene oxidation mechanism as it relates to $\mathrm{HCHO}$ production under low- $\mathrm{NO}_{\mathrm{x}}$ conditions, (2) the coupling between transport and chemistry determining the displacement between observed
HCHO columns and precursor isoprene emissions. The latter could be addressed by using a CTM adjoint inversion (Stavrakou et al., 2009a). This will eventually be necessary if we are to exploit the fine resolution of the satellite observations $\left(13 \times 24 \mathrm{~km}^{2}\right.$ in nadir for OMI) to obtain correspondingly fine constraints on isoprene emission. However, the value of such an approach is hampered at present by inadequate knowledge of the time-dependent $\mathrm{HCHO}$ yields from isoprene oxidation under low- $\mathrm{NO}_{\mathrm{x}}$ conditions, and by the difficulty of representing the coupling between transport and chemistry over timescales relevant to boundary layer mixing and mesoscale motions. Future progress most critically requires an improved understanding of isoprene oxidation chemistry through laboratory and field measurements.

Acknowledgements. This work was funded by NASA through the Aura Science Team and by a South African National Research Scholarship for Study Abroad to EAM. EAM would like to thank Omar Torres and Folkert Boersma for assistance with OMI satellite products; Sarith Mahanama and Randal Koster for providing updated soil moisture assimilated data over Africa; and the reviewers and J.-F. Müller for suggested manuscript improvements. DBM acknowledges support from NASA ACMAP (\#NNX10AG65G).

Edited by: P. O. Wennberg 


\section{References}

Abbot, D. S., Palmer, P. I., Martin, R. V., Chance, K. V., Jacob, D. J., and Guenther, A.: Seasonal and interannual variability of North American isoprene emissions as determined by formaldehyde column measurements from space, Geophys. Res. Lett., 30, 1886, doi:10.1029/2003GL017336, 2003.

Ahn, C., Torres, O., and Bhartia, P. K.: Comparison of Ozone Monitoring Instrument UV Aerosol Products with Aqua/Moderate Resolution Imaging Spectroradiometer and Multiangle Imaging Spectroradiometer observations in 2006, J. Geophys. Res., 113, D16S27, doi:10.1029/2007JD008832, 2008.

Alvarado, M. J., Logan, J. A., Mao, J., Apel, E., Riemer, D., Blake, D., Cohen, R. C., Min, K.-E., Perring, A. E., Browne, E. C., Wooldridge, P. J., Diskin, G. S., Sachse, G. W., Fuelberg, H., Sessions, W. R., Harrigan, D. L., Huey, G., Liao, J., Case-Hanks, A., Jimenez, J. L., Cubison, M. J., Vay, S. A., Weinheimer, A. J., Knapp, D. J., Montzka, D. D., Flocke, F. M., Pollack, I. B., Wennberg, P. O., Kurten, A., Crounse, J., St. Clair, J. M., Wisthaler, A., Mikoviny, T., Yantosca, R. M., Carouge, C. C., and Le Sager, P.: Nitrogen oxides and PAN in plumes from boreal fires during ARCTAS-B and their impact on ozone: an integrated analysis of aircraft and satellite observations, Atmos. Chem. Phys., 10, 9739-9760, doi:10.5194/acp-10-9739-2010, 2010.

Arneth, A., Monson, R. K., Schurgers, G., Niinemets, Ü., and Palmer, P. I.: Why are estimates of global terrestrial isoprene emissions so similar (and why is this not so for monoterpenes)?, Atmos. Chem. Phys., 8, 4605-4620, doi:10.5194/acp-8-46052008, 2008.

Barkley, M. P., Palmer, P. I., Kuhn, U., Kesselmeier, J., Chance, K., Kurosu, T. P., Martin, R. V., Helmig, D., and Guenther, A.: Net ecosystem fluxes of isoprene over tropical South America inferred from Global Ozone Monitoring Experiment (GOME) observations of HCHO columns, J. Geophys. Res., 113, D20304, doi:10.1029/2008JD009863, 2008.

Bartholomé, E. and Belward, A. S.: GLC2000: a new approach to global land cover mapping from Earth observation data, Int. J. Remote Sens., 26, 1959-1977, 2005.

Bey, I., Jacob, D. J., Yantosca, R. M., Logan, J. A., Field, B. D., Fiore, A. M., Li, Q., Liu, H. Y., Mickley, L. J., and Schultz, M. G.: Global modeling of tropospheric chemistry with assimilated meteorology: Model description and evaluation, J. Geophys. Res., 106, 23073-23095, doi:10.1029/2001JD000807, 2001.

Boersma, K. F., Eskes, H. J., Veefkind, J. P., Brinksma, E. J., van der A, R. J., Sneep, M., van den Oord, G. H. J., Levelt, P. F., Stammes, P., Gleason, J. F., and Bucsela, E. J.: Near-real time retrieval of tropospheric $\mathrm{NO}_{2}$ from OMI, Atmos. Chem. Phys., 7, 2103-2118, doi:10.5194/acp-7-2103-2007, 2007.

Boersma, K. F., Jacob, D. J., Eskes, H. J., Pinder, R. W., Wang, J., and van der A, R. J.: Intercomparison of SCIAMACHY and OMI tropospheric $\mathrm{NO}_{2}$ columns: Observing the diurnal evolution of chemistry and emissions from space, J. Geophys. Res., 113, D16S26, doi:10.1029/2007JD008816, 2008.

Casadio, S., Arino, O., and Serpe, D.: Gas flaring monitoring from space using the ATSR instrument series, Remote Sens. Environ., 116, 239-249, doi:10.1016/j.rse.2010.11.022, 2012.

Chance, K., Palmer, P. I., Spurr, R. J. D., Martin, R. V., Kurosu, T. P., and Jacob, D. J.: Satellite observations of formaldehyde over North America from GOME, Geophys. Res. Lett., 27, 34613464, doi:10.1029/2000GL011857, 2000.
Claeys, M., Graham, B., Vas, G., Wang, W., Vermeylen, R., Pashynska, V., Cafmeyer, J., Guyon, P., Andreae, M. O., Artaxo, P., and Maenhaut, W.: Formation of secondary organic aerosols through photooxidation of isoprene, Science, 303, 1173-1176, 2004.

Commane, R., Floquet, C. F. A., Ingham, T., Stone, D., Evans, M. J., and Heard, D. E.: Observations of $\mathrm{OH}$ and $\mathrm{HO}_{2}$ radicals over West Africa, Atmos. Chem. Phys., 10, 8783-8801, doi:10.5194/acp-10-8783-2010, 2010.

Crounse, J. D., Paulot, F., Kjaergaard, H. G., and Wennberg, P. O.: Peroxy radical isomerization in the oxidation of isoprene, Phys. Chem. Chem. Phys., 13, 13607-13613, 2011.

Curci, G., Palmer, P. I., Kurosu, T. P., Chance, K., and Visconti, G.: Estimating European volatile organic compound emissions using satellite observations of formaldehyde from the Ozone Monitoring Instrument, Atmos. Chem. Phys., 10, 11501-11517, doi:10.5194/acp-10-11501-2010, 2010.

De Smedt, I., Müller, J.-F., Stavrakou, T., van der A, R., Eskes, H., and Van Roozendael, M.: Twelve years of global observations of formaldehyde in the troposphere using GOME and SCIAMACHY sensors, Atmos. Chem. Phys., 8, 4947-4963, doi:10.5194/acp-8-4947-2008, 2008.

Dufour, G., Wittrock, F., Camredon, M., Beekmann, M., Richter, A., Aumont, B., and Burrows, J. P.: SCIAMACHY formaldehyde observations: constraint for isoprene emission estimates over Europe?, Atmos. Chem. Phys., 9, 1647-1664, doi:10.5194/acp-91647-2009, 2009.

Eddingsaas, N. C., VanderVelde, D. G., and Wennberg, P. O.: Kinetics and products of the acid-catalyzed ring-opening of atmospherically relevant butyl epoxy alcohols, J. Phys. Chem. A, 114, 8106-8113, 2010.

Emmerson, K. M. and Evans, M. J.: Comparison of tropospheric gas-phase chemistry schemes for use within global models, Atmos. Chem. Phys., 9, 1831-1845, doi:10.5194/acp-9-1831-2009, 2009.

Ferreira, J., Reeves, C. E., Murphy, J. G., Garcia-Carreras, L., Parker, D. J., and Oram, D. E.: Isoprene emissions modelling for West Africa: MEGAN model evaluation and sensitivity analysis, Atmos. Chem. Phys., 10, 8453-8467, doi:10.5194/acp-10-84532010, 2010.

Fiore, A. M., Levy II, H., and Jaffe, D. A.: North American isoprene influence on intercontinental ozone pollution, Atmos. Chem. Phys., 11, 1697-1710, doi:10.5194/acp-11-1697-2011, 2011.

Friedl, M. A., McIver, D. K., Hodges, J. C. F., Zhang, X. Y., Muchoney, D., Strahler, A. H., Woodcock, C. E., Gopal, S., Schneider, A., Cooper, A., Baccini, A., Gao, F., and Schaaf, C.: Global land cover mapping from MODIS: algorithms and early results, Remote Sens. Environ., 83, 287-302, 2002.

Fu, T.-M., Jacob, D. J., Palmer, P. I., Chance, K., Wang, Y. X., Barletta, B., Blake, D. R., Stanton, J. C., and Pilling, M. $\mathrm{J}$.: Space-based formaldehyde measurements as constraints on volatile organic compound emissions in east and south Asia and implications for ozone, J. Geophys. Res., 112, D06312, doi:10.1029/2006JD007853, 2007.

Giglio, L., Descloitres, J., Justice, C. O., and Kaufman, Y. J.: An enhanced contextual fire detection algorithm for MODIS, Remote Sens. Environ., 87, 273-282, 2003.

Greenberg, J. P., Guenther, A. B., Madronich, S., Baugh, W., Ginoux, P., Druilhet, A., Delmas, R., and Delon, C.: Biogenic volatile organic compound emissions in central Africa during 
the Experiment for the Regional Sources and Sinks of Oxidants (EXPRESSO) biomass burning season, J. Geophys. Res., 104, 30659-30671, doi:10.1029/1999JD900475, 1999.

Greenberg, J. P., Guenther, A., Harley, P., Otter, L., Veenendaal, E. M., Hewitt, C. N., James, A. E., and Owen, S. M.: Eddy flux and leaf-level measurements of biogenic VOC emissions from mopane woodland of Botswana, J. Geophys. Res., 108, 8466, doi:10.1029/2002JD002317, 2003.

Guenther, A., Hewitt, C. N., Erickson, D., Fall, R., Geron, C., Graedel, T., Harley, P., Klinger, L., Lerdau, M., McKay, W. A., Pierce, T., Scholes, B., Steinbrecher, R., Tallamraju, R., Taylor, J., and Zimmerman, P.: A global model of natural volatile organic compound emissions, J. Geophys. Res., 100, 8873-8892, doi:10.1029/94JD02950, 1995.

Guenther, A., Otter, L., Zimmerman, P., Greenberg, J., Scholes, R., and Scholes, M.: Biogenic hydrocarbon emissions from southern African savannas, J. Geophys. Res., 101, 25859-25865, doi:10.1029/96JD02597, 1996.

Guenther, A., Karl, T., Harley, P., Wiedinmyer, C., Palmer, P. I., and Geron, C.: Estimates of global terrestrial isoprene emissions using MEGAN (Model of Emissions of Gases and Aerosols from Nature), Atmos. Chem. Phys., 6, 3181-3210, doi:10.5194/acp-63181-2006, 2006.

Hak, C., Pundt, I., Trick, S., Kern, C., Platt, U., Dommen, J., Ordóñez, C., Prévôt, A. S. H., Junkermann, W., Astorga-Lloréns, C., Larsen, B. R., Mellqvist, J., Strandberg, A., Yu, Y., Galle, B., Kleffmann, J., Lörzer, J. C., Braathen, G. O., and Volkamer, R.: Intercomparison of four different in-situ techniques for ambient formaldehyde measurements in urban air, Atmos. Chem. Phys., 5, 2881-2900, doi:10.5194/acp-5-2881-2005, 2005.

Harley, P., Otter, L., Guenther, A., and Greenberg, J.: Micrometeorological and leaf-level measurements of isoprene emissions from a southern African savanna, J. Geophys. Res., 108, 8468, doi:10.1029/2002JD002592, 2003.

Henze, D. K. and Seinfeld, J. H.: Global secondary organic aerosol from isoprene oxidation, Geophys. Res. Lett., 33, L09812, doi:10.1029/2006GL025976, 2006.

Hobbs, P. V., Reid, J. S., Herring, J. A., Nance, J. D., Weiss, R. E., Ross, J. L., Hegg, D. A., Ottmar, R. D., and Liousse, C.: Particle and trace gas measurements in the smoke from prescribed burns of forest products in the Pacific Northwest, in: Biomass Burning and Global Change, edited by: Levine, J. S., MIT Press, Cambridge, MA, 697-715, 1996.

Hopkins, J. R., Evans, M. J., Lee, J. D., Lewis, A. C., Marsham, J. H., McQuaid, J. B., Parker, D. J., Stewart, D. J., Reeves, C. E., and Purvis, R. M.: Direct estimates of emissions from the megacity of Lagos, Atmos. Chem. Phys., 9, 8471-8477, doi:10.5194/acp-9-8471-2009, 2009.

Horowitz, L. W., Liang, J., Gardner, G. M., and Jacob, D. J.: Export of reactive nitrogen from North America during summertime: Sensitivity to hydrocarbon chemistry, J. Geophys. Res., 103, 13451-13476, doi:10.1029/97JD03142, 1998.

Jaeglé, L., Steinberger, L., Martin, R. V., and Chance, K.: Global partitioning of $\mathrm{NO}_{\mathrm{x}}$ sources using satellite observations: Relative roles of fossil fuel combustion, biomass burning and soil emissions, Faraday Discuss., 130, 407-423, 2005.

Janicot, S., Thorncroft, C. D., Ali, A., Asencio, N., Berry, G., Bock, O., Bourles, B., Caniaux, G., Chauvin, F., Deme, A., Kergoat, L., Lafore, J.-P., Lavaysse, C., Lebel, T., Marticorena, B., Mounier,
F., Nedelec, P., Redelsperger, J.-L., Ravegnani, F., Reeves, C. E., Roca, R., de Rosnay, P., Schlager, H., Sultan, B., Tomasini, M., Ulanovsky, A., and ACMAD forecasters team: Large-scale overview of the summer monsoon over West Africa during the AMMA field experiment in 2006, Ann. Geophys., 26, 25692595, doi:10.5194/angeo-26-2569-2008, 2008.

Karl, T., Potosnak, M., Guenther, A., Clark, D., Walker, J., Herrick, J. D., and Geron, C.: Exchange processes of volatile organic compounds above a tropical rain forest: Implications for modeling tropospheric chemistry above dense vegetation, J. Geophys. Res., 109, D18306, doi:10.1029/2004JD004738, 2004.

Karl, T., Guenther, A., Turnipseed, A., Tyndall, G., Artaxo, P., and Martin, S.: Rapid formation of isoprene photo-oxidation products observed in Amazonia, Atmos. Chem. Phys., 9, 7753-7767, doi:10.5194/acp-9-7753-2009, 2009.

Karl, T., Harley, P., Emmons, L., Thornton, B., Guenther, A., Basu, C., Turnipseed, A., and Jardine, K.: Efficient atmospheric cleansing of oxidized organic trace gases by vegetation, Science, 330 , 816-819, 2010.

Kim, J. H., Kim, S. M., Baek, K. H., Wang, L., Kurosu, T., De Smedt, I., Chance, K., and Newchurch, M. J.: Evaluation of satellite-derived $\mathrm{HCHO}$ using statistical methods, Atmos. Chem. Phys. Discuss., 11, 8003-8025, doi:10.5194/acpd11-8003-2011, 2011.

Kleipool, Q. L., Dobber, M. R., de Haan, J. F., and Levelt, P. F.: Earth surface reflectance climatology from 3 years of OMI data, J. Geophys. Res., 113, D18308, doi:10.1029/2008JD010290, 2008.

Klinger, L. F., Greenberg, J., Guenther, A., Tyndall, G., Zimmerman, P., M'Bangui, M., Moutsamboté, J.-M., and Kenfack, D.: Patterns in volatile organic compound emissions along a savanna-rainforest gradient in central Africa, J. Geophys. Res., 103, 1443-1454, doi:10.1029/97JD02928, 1998.

Koelemeijer, R. B. A. and Stammes, P.: Validation of Global Ozone Monitoring Experiment cloud fractions relevant for accurate ozone column retrieval, J. Geophys. Res., 104, 18801-18814, doi:10.1029/1999JD900279, 1999.

Koster, R. D., Suarez, M. J., Ducharne, A., Stieglitz, M., and Kumar, P.: A catchment-based approach to modeling land surface processes in a general circulation model 1, Model structure, J. Geophys. Res., 105, 24809-24822, doi:10.1029/2000JD900327, 2000.

Kroll, J. H., Ng, N. L., Murphy, S. M., Flagan, R. C., and Seinfeld, J. H.: Secondary organic aerosol formation from isoprene photooxidation, Environ. Sci. Technol., 40, 1869-1877, 2006.

Lelieveld, J., Butler, T. M., Crowley, J. N., Dillon, T. J., Fischer, H., Ganzeveld, L., Harder, H., Lawrence, M. G., Martinez, M., Taraborrelli, D., and Williams, J.: Atmospheric oxidation capacity sustained by a tropical forest, Nature, 452, 737-740, 2008.

Levelt, P. F., van den Oord, G. H. J., Dobber, M. R., Mälkki, A., Visser, H., de Fries, J., Stammes, P., Lundell, J. O. V., and Saari, H.: The Ozone Monitoring Instrument, IEEE T. Geosci. Remote Sens., 44, 1093-1101, 2006.

Manly, B. F. J.: Randomization, bootstrap and Monte Carlo methods in biology, Chapman and Hall, New York., 1997.

Mao, J., Jacob, D. J., Evans, M. J., Olson, J. R., Ren, X., Brune, W. H., St. Clair, J. M., Crounse, J. D., Spencer, K. M., Beaver, M. R., Wennberg, P. O., Cubison, M. J., Jimenez, J. L., Fried, A., Weibring, P., Walega, J. G., Hall, S. R., Weinheimer, A. J., Co- 
hen, R. C., Chen, G., Crawford, J. H., McNaughton, C., Clarke, A. D., Jaeglé, L., Fisher, J. A., Yantosca, R. M., Le Sager, P., and Carouge, C.: Chemistry of hydrogen oxide radicals $\left(\mathrm{HO}_{\mathrm{x}}\right)$ in the Arctic troposphere in spring, Atmos. Chem. Phys., 10, 58235838, doi:10.5194/acp-10-5823-2010, 2010.

Mari, C. H., Cailley, G., Corre, L., Saunois, M., Attié, J. L., Thouret, V., and Stohl, A.: Tracing biomass burning plumes from the Southern Hemisphere during the AMMA 2006 wet season experiment, Atmos. Chem. Phys., 8, 3951-3961, doi:10.5194/acp8-3951-2008, 2008.

Meyer-Arnek, J., Ladstätter-Weißenmayer, A., Richter, A., Wittrock, F., and Burrows, J. P.: A study of the trace gas columns of $\mathrm{O}_{3}, \mathrm{NO}_{2}$ and $\mathrm{HCHO}$ over Africa in September 1997, Faraday Discuss., 130, 387-405, 2005.

Millet, D. B., Jacob, D. J., Turquety, S., Hudman, R. C., Wu, S., Fried, A., Walega, J., Heikes, B. G., Blake, D. R., Singh, H. B., Anderson, B. E., and Clarke, A. D.: Formaldehyde distribution over North America: Implications for satellite retrievals of formaldehyde columns and isoprene emission, J. Geophys. Res., 111, D24S02, doi:10.1029/2005JD006853, 2006.

Millet, D. B., Jacob, D. J., Boersma, K. F., Fu, T.-M., Kurosu, T. P., Chance, K., Heald, C. L., and Guenther, A.: Spatial distribution of isoprene emissions from North America derived from formaldehyde column measurements by the OMI satellite sensor, J. Geophys. Res., 113, D02307, doi:10.1029/2007JD008950, 2008.

Moore, D. P. and Remedios, J. J.: Seasonality of Peroxyacetyl nitrate (PAN) in the upper troposphere and lower stratosphere using the MIPAS-E instrument, Atmos. Chem. Phys., 10, 6117-6128, doi:10.5194/acp-10-6117-2010, 2010.

Müller, J.-F., Stavrakou, T., Wallens, S., De Smedt, I., Van Roozendael, M., Potosnak, M. J., Rinne, J., Munger, B., Goldstein, A., and Guenther, A. B.: Global isoprene emissions estimated using MEGAN, ECMWF analyses and a detailed canopy environment model, Atmos. Chem. Phys., 8, 1329-1341, doi:10.5194/acp-81329-2008, 2008.

Murphy, J. G., Oram, D. E., and Reeves, C. E.: Measurements of volatile organic compounds over West Africa, Atmos. Chem. Phys., 10, 5281-5294, doi:10.5194/acp-10-5281-2010, 2010.

Oketola, A. A. and Osibanjo, O.: Estimating sectoral pollution load in Lagos by Industrial Pollution Projection System (IPPS), Sci. Total Environ., 377, 125-141, 2007.

Olivier, J. G. J., Bouwman, A. F., van der Maas, C. W. M., Berdowski, J. J. M., Veldt, C., Bloos, J. P. J., Visschedijk, A. J. H., Zandveld, P. Y. J., and Haverlag, J. L.: Description of EDGAR Version 2.0: A set of global emission inventories of greenhouse gases and ozone-depleting substances for all anthropogenic and most natural sources on a per country basis and on $1 \times 1^{\circ}$ grid, Bilthoven, The Netherlands., 1996 .

Olson, D. M., Dinerstein, E., Wikramanayake, E. D., Burgess, N. D., Powell, G. V. N., Underwood, E. C., D'amico, J. A., Itoua, I., Strand, H. E., Morrison, J. C., Loucks, C. J., Allnutt, T. F., Rickets, T. H., Kura, Y., Lamoreux, J. F., Wettengel, W. W., Hedao, P., and Kassem, K. R.: Terrestrial ecoregions of the world: a new map of life on earth, BioScience, 51, 933-938, 2001.

Otter, L. B., Guenther, A., and Greenberg, J.: Seasonal and spatial variations in biogenic hydrocarbon emissions from southern African savannas and woodlands, Atmos. Environ., 36, 42654275, 2002.
Otter, L., Guenther, A., Wiedinmyer, C., Fleming, G., Harley, P., and Greenberg, J.: Spatial and temporal variations in biogenic volatile organic compound emissions for Africa south of the equator, J. Geophys. Res., 108, 8505, doi:10.1029/2002JD002609, 2003.

Palmer, P. I., Jacob, D. J., Chance, K., Martin, R. V., Spurr, R. J. D., Kurosu, T. P., Bey, I., Yantosca, R., Fiore, A., and Li, Q.: Air mass factor formulation for spectroscopic measurements from satellites: Application to formaldehyde retrievals from the Global Ozone Monitoring Experiment, J. Geophys. Res., 106, 1453914550, doi:10.1029/2000JD900772, 2001.

Palmer, P. I., Jacob, D. J., Fiore, A. M., Martin, R. V., Chance, K., and Kurosu, T. P.: Mapping isoprene emissions over North America using formaldehyde column observations from space, J. Geophys. Res., 108, 4180, doi:10.1029/2002JD002153, 2003.

Palmer, P. I., Abbot, D. S., Fu, T.-M., Jacob, D. J., Chance, K., Kurosu, T. P., Guenther, A., Wiedinmyer, C., Stanton, J. C., Pilling, M. J., Pressley, S. N., Lamb, B., and Sumner, A. L.: Quantifying the seasonal and interannual variability of North American isoprene emissions using satellite observations of the formaldehyde column, J. Geophys. Res., 111, D12315, doi:10.1029/2005JD006689, 2006.

Park, R. J., Jacob, D. J., Field, B. D., Yantosca, R. M., and Chin, M.: Natural and transboundary pollution influences on sulfate-nitrate-ammonium aerosols in the United States: Implications for policy, J. Geophys. Res., 109, D15204, doi:10.1029/2003JD004473, 2004.

Paulot, F., Crounse, J. D., Kjaergaard, H. G., Kroll, J. H., Seinfeld, J. H., and Wennberg, P. O.: Isoprene photooxidation: new insights into the production of acids and organic nitrates, Atmos. Chem. Phys., 9, 1479-1501, doi:10.5194/acp-9-1479-2009, 2009a.

Paulot, F., Crounse, J. D., Kjaergaard, H. G., Kürten, A., St Clair, J. M., Seinfeld, J. H., and Wennberg, P. O.: Unexpected epoxide formation in the gas-phase photooxidation of isoprene, Science, 325, 730-733, 2009b.

Paulson, S. E., Flagan, R. C., and Seinfeld, J. H.: Atmospheric photooxidation of isoprene. I: The hydroxyl radical and ground state atomic oxygen reactions, Int. J. Chem. Kinet., 24, 79-101, 1992.

Peeters, J. and Müller, J.-F.: $\mathrm{HO}_{\mathrm{x}}$ radical regeneration in isoprene oxidation via peroxy radical isomerisations. II: experimental evidence and global impact, Phys. Chem. Chem. Phys., 12, 1422714235, 2010.

Peeters, J., Nguyen, T. L., and Vereecken, L.: $\mathrm{HO}_{x}$ radical regeneration in the oxidation of isoprene, Phys. Chem. Chem. Phys., 11, 5935-5939, 2009.

Redelsperger, J.-L., Thorncroft, C. D., Diedhiou, A., Lebel, T., Parker, D. J., and Polcher, J.: African Monsoon Multidisciplinary Analysis (AMMA): An international research project and field campaign, B. Am. Meteorol. Soc., 87, 1739-1746, 2006.

Reeves, C. E., Formenti, P., Afif, C., Ancellet, G., Attié, J.-L., Bechara, J., Borbon, A., Cairo, F., Coe, H., Crumeyrolle, S., Fierli, F., Flamant, C., Gomes, L., Hamburger, T., Jambert, C., Law, K. S., Mari, C., Jones, R. L., Matsuki, A., Mead, M. I., Methven, J., Mills, G. P., Minikin, A., Murphy, J. G., Nielsen, J. K., Oram, D. E., Parker, D. J., Richter, A., Schlager, H., Schwarzenboeck, A., and Thouret, V.: Chemical and aerosol characterisation of the troposphere over West Africa during the monsoon period as part of AMMA, Atmos. Chem. Phys., 10, 7575-7601, doi:10.5194/acp-10-7575-2010, 2010. 
Ren, X., Olson, J. R., Crawford, J. H., Brune, W. H., Mao, J., Long, R. B., Chen, Z., Chen, G., Avery, M. A., Sachse, G. W., Barrick, J. D., Diskin, G. S., Huey, L. G., Fried, A., Cohen, R. C., Heikes, B., Wennberg, P. O., Singh, H. B., Blake, D. R., and Shetter, R. E.: $\mathrm{HO}_{\mathrm{x}}$ chemistry during INTEX-A 2004: Observation, model calculation, and comparison with previous studies, J. Geophys. Res., 113, D05310, doi:10.1029/2007JD009166, 2008.

Saunders, S. M., Jenkin, M. E., Derwent, R. G., and Pilling, M. J.: Protocol for the development of the Master Chemical Mechanism, MCM v3 (Part A): tropospheric degradation of nonaromatic volatile organic compounds, Atmos. Chem. Phys., 3, 161-180, doi:10.5194/acp-3-161-2003, 2003.

Saxton, J. E., Lewis, A. C., Kettlewell, J. H., Ozel, M. Z., Gogus, F., Boni, Y., Korogone, S. O. U., and Serça, D.: Isoprene and monoterpene measurements in a secondary forest in northern Benin, Atmos. Chem. Phys., 7, 4095-4106, doi:10.5194/acp-74095-2007, 2007.

Serça, D., Guenther, A., Klinger, L., Vierling, L., Harley, P., Druilhet, A., Greenberg, J., Baker, B., Baugh, W., Bouka-Biona, C., and Loemba-Ndembi, J.: EXPRESSO flux measurements at upland and lowland Congo tropical forest site, Tellus B, 53, 220234, 2001.

Shim, C., Wang, Y., Choi, Y., Palmer, P. I., Abbot, D. S., and Chance, K.: Constraining global isoprene emissions with Global Ozone Monitoring Experiment (GOME) formaldehyde column measurements, J. Geophys. Res., 110, D24301, doi:10.1029/2004JD005629, 2005.

Singh, H. B. and Hanst, P. L.: Peroxyacetyl nitrate (PAN) in the unpolluted atmosphere: An important reservoir for nitrogen oxides, Geophys. Res. Lett., 8, 941-944, 1981.

South African Petroleum Industry Association (SAPIA): Annual Report., 2008.

Spurr, R. J. D., Kurosu, T. P., and Chance, K. V.: A linearized discrete ordinate radiative transfer model for atmospheric remotesensing retrieval, J. Quant. Spectrosc. Ra., 68, 689-735, 2001.

Stammes, P., Sneep, M., de Haan, J. F., Veefkind, J. P., Wang, P., and Levelt, P. F.: Effective cloud fractions from the Ozone Monitoring Instrument: Theoretical framework and validation, J. Geophys. Res., 113, D16S38, doi:10.1029/2007JD008820, 2008.

Stavrakou, T., Müller, J.-F., De Smedt, I., Van Roozendael, M., van der Werf, G. R., Giglio, L., and Guenther, A.: Global emissions of non-methane hydrocarbons deduced from SCIAMACHY formaldehyde columns through 2003-2006, Atmos. Chem. Phys., 9, 3663-3679, doi:10.5194/acp-9-3663-2009, 2009a.

Stavrakou, T., Müller, J.-F., De Smedt, I., Van Roozendael, M., van der Werf, G. R., Giglio, L., and Guenther, A.: Evaluating the performance of pyrogenic and biogenic emission inventories against one decade of space-based formaldehyde columns, Atmos. Chem. Phys., 9, 1037-1060, doi:10.5194/acp-9-1037-2009, $2009 b$

Stewart, D. J., Taylor, C. M., Reeves, C. E., and McQuaid, J. B.: Biogenic nitrogen oxide emissions from soils: impact on $\mathrm{NO}_{\mathrm{x}}$ and ozone over west Africa during AMMA (African Monsoon Multidisciplinary Analysis): observational study, Atmos. Chem. Phys., 8, 2285-2297, doi:10.5194/acp-8-2285-2008, 2008.

Stone, D., Evans, M. J., Commane, R., Ingham, T., Floquet, C. F. A., McQuaid, J. B., Brookes, D. M., Monks, P. S., Purvis, R., Hamilton, J. F., Hopkins, J., Lee, J., Lewis, A. C., Stewart, D., Murphy, J. G., Mills, G., Oram, D., Reeves, C. E., and Heard,
D. E.: $\mathrm{HO}_{\mathrm{x}}$ observations over West Africa during AMMA: impact of isoprene and $\mathrm{NO}_{\mathrm{x}}$, Atmos. Chem. Phys., 10, 9415-9429, doi:10.5194/acp-10-9415-2010, 2010.

Sumner, A. L., Shepson, P. B., Couch, T. L., Thornberry, T., Carroll, M. A., Sillman, S., Pippin, M., Bertman, S., Tan, D., Faloona, I., Brune, W., Young, V., Cooper, O., Moody, J., and Stockwell, W.: A study of formaldehyde chemistry above a forest canopy, J. Geophys. Res., 106, 24387-24405, doi:10.1029/2000JD900761, 2001.

Tao, Z., Larson, S. M., Wuebbles, D. J., Williams, A., and Caughey, M.: A summer simulation of biogenic contributions to groundlevel ozone over the continental United States, J. Geophys. Res., 108, 4404, doi:10.1029/2002JD002945, 2003.

Taraborrelli, D., Lawrence, M. G., Crowley, J. N., Dillon, T. J., Gromov, S., Groß, C. B. M., Vereecken, L., and Lelieveld, J.: Hydroxyl radical buffered by isoprene oxidation over tropical forests, Nature Geoscience, 5, 190-193, doi:10.1038/NGEO1405, 2012.

Torres, O., Tanskanen, A., Veihelmann, B., Ahn, C., Braak, R., Bhartia, P. K., Veefkind, P., and Levelt, P.: Aerosols and surface UV products from Ozone Monitoring Instrument observations: An overview, J. Geophys. Res., 112, D24S47, doi:10.1029/2007JD008809, 2007.

Trainer, M., Williams, E. J., Parrish, D. D., Buhr, M. P., Allwine, E. J., Westberg, H. H., Fehsenfeld, F. C., and Liu, S. C.: Models and observations of the impact of natural hydrocarbons on rural ozone, Nature, 329, 705-707, 1987.

Trentmann, J., Andreae, M. O., and Graf, H.-F.: Chemical processes in a young biomass-burning plume, J. Geophys. Res., 108, 4705, doi:10.1029/2003JD003732, 2003.

US EPA: Estimation Programs Interface for Windows Vista v4.10, US EPA, 2011.

van der Werf, G. R., Randerson, J. T., Giglio, L., Collatz, G. J., Kasibhatla, P. S., and Arellano Jr., A. F.: Interannual variability in global biomass burning emissions from 1997 to 2004, Atmos. Chem. Phys., 6, 3423-3441, doi:10.5194/acp-6-3423-2006, 2006.

Wang, Y., Jacob, D. J., and Logan, J. A.: Global simulation of tropospheric $\mathrm{O}_{3}-\mathrm{NO}_{\mathrm{x}}$-hydrocarbon chemistry, 1. Model formulation, J. Geophys. Res., 103, 10713-10725, doi:10.1029/98JD00158, 1998.

Wesely, M. L.: Parameterization of surface resistances to gaseous dry deposition in regional-scale numerical models, Atmos. Environ., 23, 1293-1304, 1989.

Yang, W., Shabanov, N. V., Huang, D., Wang, W., Dickinson, R. E., Nemani, R. R., Knyazikhin, Y., and Myneni, R. B.: Analysis of leaf area index products from combination of MODIS Terra and Aqua data, Remote Sens. Environ., 104, 297-312, 2006.

Yevich, R. and Logan, J. A.: An assessment of biofuel use and burning of agricultural waste in the developing world, Global Biogeochem. Cy., 17, 1095, doi:10.1029/2002GB001952, 2003.

Yienger, J. J. and Levy II, H.: Empirical model of global soilbiogenic $\mathrm{NO}_{\mathrm{x}}$ emissions, J. Geophys. Res., 100, 11447-11464, doi:10.1029/95JD00370, 1995.

Zeng, X.: Global vegetation root distribution for land modeling, J. Hydrometeorol., 2, 525-530, 2001. 